\title{
NEWT GINGRICH, DYNAMIC STATUTORY INTERPRETER
}

DYNAMIC STATUTORY INTERPRETATION. By William N. Eskridge, Jr. $\dagger$ Harvard University Press 1994. Pp. 438. \$49.95.

\section{JOHN COPELAND NAGLE††}

\section{INTRODUCTION}

Choosing any two months as pivotal in the development of statutory interpretation doctrine is a perilous enterprise, but two events occurred in November and December 1994 that lead me to try. The second event, the publication of Professor William Eskridge's book, Dynamic Statutory Interpretation, ${ }^{1}$ was expected. The first event, the Republican Party's capture of both houses of Congress, was entirely unexpected. The coincidence of this book and this election may signal the beginning of a reevaluation of the theories of statutory interpretation prevailing in the academy and in the courts.

Dynamic Statutory Interpretation marks the culmination of a decade of Professor Eskridge's prolific scholarship. ${ }^{2}$ The sheer

† Professor, Georgetown University Law Center.

t+ Associate Professor, Seton Hall University School of Law. B.A. 1982, Indiana University; J.D. 1986, University of Michigan Law School. I am indebted to Abner Greene, Ed Hartnett, Mark Movsesian, Lisa Nagle, Mike Paulsen, Marc Poirier, Frederick Schauer, and Charlie Sullivan for their thoughts and comments. I also thank Ed DuMont for his gracious help and Steve Skinner for his valuable research assistance.

1 William N. Eskridge, JR., Dynamic Statutory Interpretation (1994) [hereinafter cited by page number only].

${ }^{2}$ Eskridge is the coauthor of the leading legislation casebook, WILLIAM N. ESKRIDGE, JR. \& PHILIP P. FRICKEY, CASES AND MATERIALS ON LEgISLATION: STATUTES AND THE CREATION OF PUBlic POLICY (1988) [hereinafter ESKRIDGe \& Frickey, LEGISLATION]. He has also written extensively on statutory interpretation. See, e.g., William N. Eskridge, Jr., Public Law from the Bottom Up, 97 W. VA. L. REV. 141 (1995); William N. Eskridge, Jr. \& John Ferejohn, Politics, Interpretation, and the Rule of Law, in THE RULE OF LAW 265 (Ian Shapiro ed., 1994) [hereinafter Eskridge \& Ferejohn, The Rule of Law]; William N. Eskridge, Jr. \& Philip P. Frickey, Foreword: Law as Equilibrium, 108 HARV. L. REV. 26 (1994) [hereinafter Eskridge \& Frickey, Foreword]; William N. Eskridge, Jr., The Case of the Speluncean Explorers: Twentieth-Century Statutory Interpretation in a Nutshell, 61 GEO. WASH. L. REV. 1731 (1993); William N. 
breadth of what Eskridge accomplishes in the book is overwhelming. He surveys a host of legal theories-originalism, legal process, postmodernism, natural law, hermeneutics, practical reasoning, feminist republicanism-and produces a work that teaches as much about legal theory in general as it does about statutory interpretation in particular. Along the way, he develops his own theory of how current political values influence the interpretation of statutes enacted under different conditions in earlier periods-a theory of "dynamic" statutory interpretation.

A long list of leading scholars have turned their attention to the theory and practice of statutory interpretation during the $1980 \mathrm{~s}$ and $1990 \mathrm{~s},{ }^{3}$ and three of the Justices now sitting on the Supreme Court

Eskridge, Jr., The Judicial Review Game, 88 Nw. U. L. REv. 382 (1993); William N. Eskridge, Jr., Cycling Legislative Intent, 12 INT'L REV. L. \& ECON. 260 (1992); William N. Eskridge, Jr. \& John Ferejohn, The Article I, Section 7 Game, 80 Geo. L.J. 523 (1992); William N. Eskridge, Jr. \& Philip P. Frickey, Quasi-Constitutional Law: Clear Statement Rules as Constitutional Lawmaking, 45 VAND. L. REV. 593 (1992); William N. Eskridge, Jr., The New Public Law Movement: Moderation as a Postmodern Cultural Form, 89 MICH. L. REV. 707 (1991); William N. Eskridge, Jr., Overriding Supreme Court Statutory Interpretation Decisions, 101 YALE L.J. 331 (1991); William N. Eskridge, Jr., Reneging on History?: Playing the Court/Congress/President Civil Rights Game, 79 CAL. L. REv. 613 (1991); William N. Eskridge, Jr., The Case of the Amorous Defendant: Criticizing Absolute Stare Decisis for Statutory Cases, 88 MICH. L. REV. 2450 (1990); William N. Eskridge, Jr., Gadamer/Statutory Interpretation, 90 CoLUM. L. REV. 609 (1990); William N. Eskridge, Jr., Legislative History Values, 66 CH.-KENT L. REV. 365 (1990); William N. Eskridge, Jr., The New Textualism, 37 UCLA L. REv. 621 (1990); William N. Eskridge, Jr. \& Philip P. Frickey, Statutory Interpretation as Practical Reasoning, 42 Stan. L. REv. 321 (1990); William N. Eskridge, Jr., Public Values in Statutory Interpretation, 137 U. PA. L. REv. 1007 (1989); William N. Eskridge, Jr., Spinning Legislative Supremacy, 78 GEO. L.J. 319 (1989); William N. Eskridge, Jr., Interpreting Legislative Inaction, 87 MICH. L. REV. 67 (1988); William N. Eskridge, Jr., Overruling Statutory Precedents, 76 GEO. L.J. 1361 (1988); William N. Eskridge, Jr., Politics Without Romance: Implications of Public Choice Theory for Statutory Interpretation, 74 VA. L. REv. 275 (1988); William N. Eskridge, Jr., Dynamic Statutory Interpretation, 135 U. PA. L. Rev. 1479 (1987); William N. Eskridge, Jr. \& Philip P. Frickey, Legislation Scholarship and Pedagogy in the Post-Legal Process Era, 48 U. PrTT. L. REV. 691 (1987). Eskridge candidly acknowledges that his articles are not entirely consistent. See p. vii (crediting those who identified the inconsistencies).

${ }^{3}$ At the risk of omission, see T. Alexander Aleinikoff, Updating Statutory Interpretation, 87 MICH. L. REV. 20 (1988); Frank H. Easterbrook, Statutes' Domains, 50 U. CHI. L. REV. 533 (1983); Daniel A. Farber, Statutory Interpretation and Legislative Supremacy, 78 Geo. L.J. 281 (1989); Philip P. Frickey, From the Big Sleep to the Big Heat: The Revival of Theory in Statutory Interpretation, 77 MINN. L. REv. 241 (1992); Thomas W. Merrill, Chief Justice Rehnquist, Pluralist Theory, and the Interpretation of Statutes, 25 RUTGERS L.J. 621 (1994); Richard A. Posner, Legal Formalism, Legal Realism, and the Interpretation of Statutes and the Constitution, 37 CASE W. RES. L. REV. 179 (1986); Frederick Schauer, Statutory Construction and the Coordinating Function of Plain Meaning, 1990 SuP. CT. REv. 231; David L. Shapiro, Continuity and Change in Statutory Interpretation, 67 N.Y.U. L. REV. 921 (1992); Cass R. Sunstein, Interpreting Statutes in 
have written academic works in the field. 4 Dynamic Statutory Interpretation stands out from this remarkable renaissance in statutory interpretation because it draws from and synthesizes all of these writings to produce one of the most comprehensive theories of statutory interpretation advanced in recent years.

Whether this theory will affect those who actually interpret statutes remains to be seen. The United States Supreme Court has been singularly unimpressed with the direction the academic literature has taken; ${ }^{5}$ instead, the Court has generally adhered to an originalist approach that emphasizes the text, intent, and purpose of a statute as the touchstones of statutory interpretation. No single theory of statutory interpretation explains all of the Court's recent decisions, ${ }^{6}$ but the Court most often employs an originalist approach, despite the overwhelming consensus among academic commentators that originalist theories are passé.?

Eskridge shares the academy's skepticism about originalism. He acknowledges the value of originalist sources-statutory text and structure, legislative history and purpose-and finds some useful insights in originalist theories. He concludes, however, that originalist approaches to statutory interpretation are undesirable in theory and unworkable in practice. Eskridge's theory of dynamic statutory interpretation asserts that statutory meaning must evolve

the Regulatory State, 103 HARV. L. REV. 405 (1989).

4 See Stephen Breyer, On the Uses of Legislative History in Interpreting Statutes, $65 \mathrm{~S}$. CAL. L. REv. 845 (1992) (defending the use of legislative history); Antonin Scalia, Judicial Deference to Administrative Interpretations of Law, 1989 DUKE L.J. 511 (discussing statutory construction in the context of administrative law); John P. Stevens, The Shakespeare Canon of Statutory Construction, 140 U. PA. L. REV. 1373 (1992) (examining the canons of statutory construction).

${ }^{5}$ See Schauer, supra note 3, at 231 (finding that the Court has ignored the academic literature); Shapiro, supra note 3, at 921-22 \& $\mathrm{n.5}$ (noting that although academics debate various theories of statutory interpretation, the Court tends to rely on the plain-meaning approach).

${ }^{6}$ Philip Frickey observes that "[t]he Supreme Court remains up for grabs. For every case that seems to be a victory of textualism, another can be found that reflects more conventional intentionalist methodologies, and the purpose approach is not dead, either." Frickey, supra note 3, at 256 (footnotes omitted).

7 See, e.g., Martin H. Redish \& Theodore T. Chung, Democratic Theory and the Legislative Process: Mourning the Death of Originalism in Statutory Interpretation, 68 TUL. L. REV. 803, 804-05 (1994) (asserting that originalism "has now become something of an endangered species among commentators on [statutory interpretation]"); Nicholas S. Zeppos, The Use of Authority in Statutory Interpretation: An Empirical Analysis, 70 TEX. L. REV. 1073, 1088 (1992) (concluding that "originalism retains no defenders in the academy ${ }^{n}$ as a theory of statutory interpretation). For a summary of Eskridge's discussion of the different originalist theories, see infra notes 15-29 and accompanying text. 
over time. For Eskridge, this evolution should track current political trends in order to achieve an interpretation of a statute that best fits the values and goals animating current legislators, administrative agencies, and other interested actors. Judges and others interpreting statutes, therefore, may properly consider the interpretation preferred by the current legislature when deciding how to interpret a statute in particular circumstances.

Eskridge's call to rely on the values of the current legislature takes on a new meaning in light of the Republican Party's gain of control over both houses of Congress for the first time since 1954. The legislative agenda previously controlled by long-term Democratic committee chairs such as Edward Kennedy, Don Edwards, and Jack Brooks is now in the hands of Jesse Helms, Robert Packwood, and Henry Hyde. The consequences of this transition are just beginning to manifest themselves. Most importantly, Newt Gingrich, the new Speaker of the House of Representatives, brings a revolutionary set of ideas to the fore of the congressional agenda that could radically alter the way the federal government conducts business with America.

The Contract with America, of which Gingrich was a primary architect, proposes numerous radical legislative reforms. The proposals include amending the Constitution to require a balanced federal budget; revamping federal welfare programs; compensating private property owners affected by environmental controls; and reforming the nation's tort system. ${ }^{8}$ The House of Representatives has already enacted the Contract's proposals, changing its operating procedures. $^{9}$

Whether Congress actually enacts any of these legislative proposals in anything similar to their original form is surely questionable, but that is not my concern here. According to Eskridge, the very existence of this new legislative agenda has consequences for interpreting existing statutes because the values held by the congressional majority are values dynamic statutory

${ }^{8}$ For a summary of the proposed legislation to implement the Contract with America, see Contract with America-Updated Overview, HOUSE REPUBLICAN CONF. LEGIS. DIG., Jan. 11, 1995.

${ }^{9}$ In a single day, the House agreed to reduce committee staff by one-third, see 141 CONG. REC. H49 (daily ed.Jan. 4, 1995); to change the rules for calculating budgetary figures, see id. at H52; to limit the terms of committee chairs and of the Speaker, see id. at H55; to prohibit proxy voting in committees, id. at H58-59; to open more committee meetings to the public, see id. at $\mathrm{H} 62-63$; and to require a supermajority vote for federal income tax increases, see id. at H71-72. 
interpreters use to guide their interpretation. Thus, the meaning of federal statutes in the world according to Newt Gingrich will be much different than the meaning of those same statutes to the Congresses that enacted them.

Eskridge could not have foreseen the direction in which congressional dynamics would move when he developed his idea of dynamic statutory interpretation. Indeed, the political culture of the 1980s-a liberal Congress controlled by the Democratic Party and a conservative presidency and judiciary controlled by the Republican Party-may have exerted a subtle influence over the liberal theories of statutory interpretation that flowered during that time. A similar point has been made with respect to conservative theories of executive power ${ }^{10}$ and statutory interpretation. ${ }^{11}$ This does not prove the correctness of any particular theory of statutory interpretation, nor does it suggest that any theory springs from partisan political considerations. But dynamic statutory interpretation will now produce politically unpopular results for those who question the new congressional agenda. ${ }^{12}$

${ }^{10}$ See Michael A. Fitts, Can Ignorance Be Bliss? Imperfect Information as a Positive Influence in Political Institutions, $88 \mathrm{MICH}$. L. REV. 917, 974 (1990) (noting that the Republican Party since 1968 has viewed its political interests "as tied to the particular institution that [it] inhabit[s]"); Lani Guinier, Lines in the Sand, 72 TEX. L. REv. 315, 335 n.112 (1993) ("The more vulgar explanation, at least for the attractiveness of Scalia's views [of separation of powers], is that in an era of conservative Republican Presidents and more liberal Democratic Congresses, a tilt toward the Presidency has obvious meaning ...."); Theodore J. Lowi, Two Roads to Serfdom: Liberalism, Conservatism and Administrative Power, 36 AM. U. L. REv. 295, 315 (1987) (noting that President Reagan's conservative opposition to the power of the executive branch ended once he entered office); Jeffrey W. Stempel, The Rehnquist Court, Statutory Interpretation, Inertial Burdens, and a Misleading Version of Democracy, 22 U. TOL. L. REV. 583, 656, 664, 673 (1991) (explaining that conservative affection for executive power increased while the Republican Party dominated presidential politics).

"See Jerry L. Marshaw, Textualism, Constitutionalism, and the Interpretation of Federal Statutes, 32 WM. \& MARY L. REV. 827, 830-32 (1991) (discussing arguments that the Court's deference to agency interpretations and its recent civil rights decisions demonstrate an attempt to undermine liberal statutes); Stephen F. Ross, Reaganist Realism Comes to Detroit, 1989 U. ILL. L. REV. 399, 420, 432 (arguing that textualism and deference to administrative interpretations favor Republican presidents over Democratic Congresses); Nicholas S. Zeppos, Chief Justice Rehnquist, the Two Faces of Ultra-Pluralism, and the Originalist Fallacy, 25 RUTGERS L.J. 679, 679 (1994) (arguing that Chief Justice Rehnquist's statutory interpretation decisions coincide with his political preferences). Eskridge does note that interpretive discretion is more attractive when those with whom one agrees are doing the interpreting. See p. 214 ( $[$ [I]nterpretive discretion was attractive [to New Deal scholars] so long as New Dealers were doing the interpreting.").

${ }^{12} \mathrm{I}$ assume that many of the academics interested in statutory interpretation dislike much of the new Republican agenda. See generally John O. McGinnis, The 
Eskridge's book raises far more issues than I could hope to address in this review. My aim rather is to counter two of Eskridge's central claims. First, Eskridge repeatedly claims that originalist approaches are just as indeterminate and no more constraining than dynamic approaches. ${ }^{13}$ This is an overstatement. Originalist stat-utory interpretation is not inevitably dynamic. Although originalist approaches are not completely determinate, it is demonstrably wrong to maintain that they are just as malleable as a dynamic approach. Second, by offering few interpretive constraints and encouraging reliance on current congressional values, Eskridge's normative argument for dynamic statutory interpretation leaves all statutes at the mercy of the current Congress for interpretive guidance.

Section I of this review describes how a dynamic statutory interpreter approaches the task of interpreting statutes. Section II

Partial Republican, 35 WM. \& MARY L. Rev. 1751, 1799 (1994) (collecting sources suggesting that " $[t]$ here is a substantial consensus among scholars of varying political views that the legal academy leans decidedly to the left side of the American political spectrum"). I am generally more supportive of what the Contract with America would do, but the point of my example is aimed at those who find Newt Gingrich's agenda scary. The early results have been predictable: a number of law professors have already sparred with Newt Gingrich regarding his proposals for change. See Bruce Ackerman et al., Dear Newt: 'Supermajority' Goes Too Far, Legal Times, Jan. 9, 1995, at 10, 11 (protesting as "restriking the constitutional balance" Newt Gingrich's proposal to amend the House rules to require a three-fifths vote to enact laws that increase income taxes).

${ }^{13}$ See pp. 299-300 ("The main objection posed by this book is that the Rehnquist Court's sources of authority-statutory text and tradition-are no 'harder' or determinate than statutory purpose and are no better at screening out value judgments by judges."); see also p. 119 (arguing that Justice Scalia's theory "fails to achieve its main stated goal of less judicial discretion in statutory interpretation"); $p$. 134 ('[B]y allowing an 'absurd result' exception to his dogmatic textualism, Scalia allowed for just as much indeterminacy, and just as much room for judicial play, as he accused Brennan of creating with his context-dependent approach to statutory meaning."); p. 230 (noting that "the new textualists' methodology is no more objective or constraining than other methodologies"); p. 233 (criticizing an opinion by Justice Scalia as revealing that "the new textualism is no more constraining than the traditional approach"). At other points in the book, Eskridge makes the narrower claim that originalist theories are especially indeterminate in hard cases. See p. 34 (noting that "textualism falls athwart the same difficulties that plague the other foundationalist theories" because it "does not yield determinate answers . . . in hard cases"). But as Daniel Rodriguez notes, Eskridge defines "hard cases" so broadly that the occasional qualification means little in practice. See Daniel B. Rodriguez, The Substance of the New Legal Process, 77 CAL. L. REV. 919, 938-39 (1989) (reviewing ESKRIDGE \& FRICKEY, LEGISLATION, supra note 2); $c f$. FREDERICK SCHAUER, PlayinG BY THE RULES 207-12 (1991) (noting that theories of interpretation determine what will be a hard case). 
rejects Eskridge's claim that dynamic statutory interpretation is empirically inevitable. I show that Eskridge exaggerates the difficulties faced by originalist theories of statutory interpretation while remaining blind to the fact that many of these same problems plague dynamic statutory interpretation. To illustrate these points, I examine Brown v. Gardner, ${ }^{14}$ a unanimous 1994 Supreme Court decision invalidating a seventy-year-old veterans' benefits regulation as contrary to the statute's plain language. Finally, Section III responds to Eskridge's claim that dynamic statutory interpretation is normatively desirable. As the ascendance of Newt Gingrich to the Speaker of the House reminds those who oppose his agenda, the Framers of the Constitution were wise to implement the formal procedures for lawmaking in Article I, Section 7, thus constraining the interpretive powers of the federal judiciary.

\section{INTERPRETING STATUTES DYNAMICALLY}

Eskridge defines dynamic statutory interpretation not by what it is, but by what it is not. Dynamic statutory interpretation is not originalist statutory interpretation. ${ }^{15}$ Eskridge classifies three distinct theories as "originalist" approaches: textualist, intentionalist, and purposive. An intentionalist approach seeks to ascertain the intent of Congress in enacting the statute. ${ }^{16}$ A purposive approach pursues an interpretation that is consistent with the purposes of the statute. ${ }^{17}$ A textualist approach interprets the statute according to the meaning of the statutory language alone. ${ }^{18}$ Each theory, therefore, seeks to ascertain the correct interpretation of the statute by reference to objective criteria gleaned from some aspect of the original statutory enactment.

Eskridge claims that all originalist theories fail because they are indeterminate, because they do not reflect a coherent view of political theory or legislatures, and because they produce norma-

14115 S. Ct. 552 (1994).

${ }^{15}$ Eskridge credits Owen Fiss and Laurens Walker for rejecting his initial label of "nonoriginalist statutory interpretation." See p. vii.

${ }^{16}$ See p. 14. Legislative intent, in turn, can mean either the specific intent of the enacting Congress or a hypothetical intent constructed by asking: What would Congress have done if it had considered this question? See pp. 16-25 (analyzing and criticizing theories of actual intent and imaginative reconstruction).

${ }^{17}$ See pp. 25-26 (discussing how purposivism resolves statutory ambiguities "first, by identifying the purpose or objective of the statute, and then by determining which interpretation is most consistent with that purpose or goal") (citation omitted).

${ }^{18}$ See p. 34 (analyzing and criticizing the theory and practice of textualism). 
tively questionable results. Eskridge is especially critical of originalist claims to produce a determinate answer in specific cases, asserting that "no originalist theory generates results in statutory cases that can objectively be tied to majority-based preferences, and originalist theories collectively cannot exclude evolutive values from statutory interpretation. ${ }^{19}$

Eskridge focuses primarily on textualism. Statutory language, says Eskridge, is hopelessly ambiguous. This ambiguity is a result of several factors. First, statutory language is written by a collective author and is rewritten by other legislatures over time. ${ }^{20}$ Second, the legislature sometimes intentionally writes ambiguous statutory language in order to avoid a controversial issue. ${ }^{21}$ Third, statutory language takes its meaning from the context in which it was written. ${ }^{22}$ Finally, the interpreter's own context and values necessarily influence the way she reads statutory language. ${ }^{23}$ As a result, "what is or is not a plain meaning is to a large extent constructed, not found, by the Court." 24

Eskridge recognizes that the Supreme Court, and Justice Scalia in particular, has developed a "holistic textualism" theory that relies on contextual constraints to "produce text-based interpretive closure even when the statutory provision being interpreted is itself ambiguous." ${ }^{25}$ The relevant contexts include textual authorities, such as dictionaries and case law extant when the legislature wrote the statute, the whole statutory text and related statutory provisions, and canons (especially clear statement rules) announcing linguistic or policy presumptions "that will govern absent clear textual contradiction." ${ }^{26}$ Reliance on these contexts allows the Court to

19 P. 10.

${ }^{20}$ See p. 38 ("Ambiguities arise because there is no single author [and] because different authors write and rewrite provisions at different times and with different goals.").

${ }^{21}$ See id. (noting that ambiguities arise because "the goals of at least some of the authors are to create rather than avoid ambiguity").

${ }^{22}$ See p. 40 ("An additional problem ... is that the meaning of text is decisively influenced by context.").

${ }^{23}$ See p. 41 ("[T]he interpreter's own context, including her situatedness in a certain generation and a certain status in our society, influences the way she reads simple texts."); see also p. 58 (noting that an interpreter is influenced by her own institutional role and by her "frame of reference-assumptions and beliefs about society, values, and the statute itself"); p. 237 ("[V]alue judgments inevitably influence the way one reads the text and legislative history of a statute ....").

${ }^{24}$ P. 290.

25 P. 42.

${ }^{26}$ Id.; see also pp. $275-97$ (elaborating on these interpretive canons). For my 
understand the statutory text without looking to legislative history or statutory purpose.

Eskridge concludes that this "holistic textualism" theory cannot negate the importance of the interpreter's own perspective. ${ }^{27}$ Further, Eskridge perceives a willingness on the part of holistic interpreters to sacrifice the force of the statutory plain meaning when it conflicts with certain other values. ${ }^{28}$ This leads Eskridge to suggest that "holistic textual analysis is no more determinate, objective, or constraining than other archaeological approaches to statutory interpretation. ${ }^{29}$

The assault on originalist theories convinces Eskridge that dynamic statutory interpretation is inevitable. "The interpretation of a statutory provision by an interpreter is not necessarily the one which the original legislature would have endorsed, and as the distance between enactment and interpretation increases, a pure originalist theory becomes impossible and/or irrelevant. ${ }^{\text {30 }}$ Sometimes dynamic statutory interpretation is inevitable because of a deliberate decision by the legislature. ${ }^{31}$ Interpretive questions

analysis of the Court's recent use of such canons, see John C. Nagle, Clear Statement Rules, 1995 WIS. L. REv. (forthcoming Sept. 1995).

${ }^{27}$ See p. 42 (asserting that holistic textualism "fails because it does no better than plain meaning to yield determinate interpretations, because the interpreter's perspective remains critical, and because even the most ardent new textualist is willing to sacrifice plain meaning for other values").

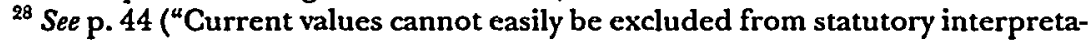
tion . . . ."). According to Eskridge, Green v. Bock Laundry Mach. Co., 490 U.S. 504 (1989), is such a case. In Bock Laundry, the Court interpreted Federal Rule of Evidence 609(a)(1)'s impeachment balancing test to apply to civil plaintiffs, notwithstanding the Rule's then-existing literal limitation to criminal defendants. See id. at 509-11 (construing an earlier version of Rule 609, Fed. R. Evid. 609(a)(1), 28 U.S.C. app. at 759 (1988) (amended 1990)). Justice Scalia concurred in the Court's holding, concluding that the plain language of Rule 609 (a)(1) would produce "an absurd, and perhaps unconstitutional, result." Id. at 527 (Scalia, J., concurring). Eskridge believes that Justice Scalia's concurrence in Bock Laundry teaches that "[b]y creating an exception to textualism when a statute requires unintended 'absurd' consequences, Scalia conceded that following statutory text is not all that is going on in statutory interpretation, and that current interpretive values also have a role to play." P. 45. Eskridge thus accuses Justice Scalia of abandoning his interpretive theory when it yields political results he dislikes. See p. 44. Nicholas Zeppos reaches a different conclusion, however, citing a number of cases in which Justice Scalia's textualist approach led him to liberal results. See Zeppos, supra note 11, at 692 n.43.

${ }^{29}$ P. 44; see also supra note 13 (collecting Eskridge's assertions that originalism is inevitably indeterminate).

${ }^{30}$ P. 5-6.

${ }^{31}$ See pp. 112-16 (discussing the common legislative practice of delegating lawmaking authority to agencies or courts to respond to changing circumstances). 
may be so controversial that they are avoided so that the legislation can proceed, ${ }^{32}$ or the legislature may use terms that it knows have "dynamic potential" because the legislature expects the courts to develop those terms in a manner analogous to the common law. ${ }^{33}$

In other instances, the apparent inevitability of dynamic statutory interpretation results not from a conscious choice by the legislature but simply from the passage of time. ${ }^{34}$ First, as time passes, unexpected disputes may arise about the meaning of the statute. Second, dynamic interpretation occurs because statutes must be interpreted "in a manner 'compatible with the surrounding body of law,' which of course changes constantly." ${ }^{\text {s5 }}$ Finally, "statutes will be construed dynamically whenever the perspective of the interpreter departs from the perspective of the statute," which increases over time with changed circumstances, other legal developments, and political changes. ${ }^{36}$

In addition to deliberate legislative choices and the passage of time, Eskridge finds dynamic statutory interpretation inevitable because interpreters work to avoid having their interpretation overruled. ${ }^{37}$ For lower courts, this means interpreting statutes in a manner that will not be overturned by higher appellate courts, and ultimately by the Supreme Court. For the Supreme Court, this means interpreting a statute in a manner that will not be legislatively corrected by Congress. ${ }^{38}$

Most traditional statutory interpreters are concerned about learning the objectively ascertainable "right" answer to an interpretive question. Not Eskridge. He candidly admits that his theory of

32 See p. 9 (noting that some issues are "politically sidestepped").

${ }^{33}$ See p. 119. Justice Scalia coined the term "dynamic potential" in Business Elec. Corp. v. Sharp Elec. Corp., 485 U.S. 717, 732 (1988).

${ }^{34}$ Eskridge distinguishes between a statute evolving beyond original expectations when "successive applications of the statute occur in contexts not anticipated by its authors," and a statute evolving against its original expectations when "subsequent applications reveal that factual or legal assumptions of the original statute have become (or were originally) erroneous." P. 49 (citing Farber, supra note 3). Eskridge identifies a third evolutionary pattern in which courts trim back a broadly written statute. See p. 140 (noting that "[1]iberalism does not object to trimming back a broadly written statute through policy exceptions").

${ }^{35}$ P. 119 (quoting Green v. Bock Laundry Mach. Co., 490 U.S. 504, 528 (1989) (Scalia, J., concurring)).

${ }^{36}$ P. 11.

${ }^{37}$ See p. 69 (noting that "the interpreter remains constrained both by the way the issue is framed for her from below and by the prospect that her interpretation will be overridden from above").

${ }^{38}$ See pp. 69-70. 
dynamic statutory interpretation presumes that no single "right" answer to specific questions of statutory interpretation can be gleaned from originalist sources or any other objective source. ${ }^{39}$ Instead, Eskridge proposes a "critical pragmatist" theory of statutory interpretation. The "critical" component of the theory uses "the interpretive moment as an opportunity to evaluate the practice in which the issue is situated, in light of criteria drawn from different political traditions," namely liberalism, legal process, and normativism. ${ }^{40}$ The "pragmatic" component results from the interpreter's "responsibility to take practice seriously and to consider the consequences of different interpretive choices." ${ }^{31}$ The pragmatic aspect of Eskridge's theory enables a dynamic statutory interpreter to find all possible sources of meaning relevant and none dispositive. ${ }^{42}$

A dynamic statutory interpreter freely relies on contemporary values when interpreting a statute. Eskridge even suggests that "the expectations of the current legislature might be more important than those of the enacting one. ${ }^{43}$ But the past does play a role for a dynamic statutory interpreter. Eskridge favors a "relational agent" metaphor in which "the agent is supposed to follow the general directives embodied in the contract and the specific orders given her by the principal, but her primary obligation is to use her best efforts to carry out the general goals and specific orders overtime." ${ }^{\text {44 }}$ The agent's fundamental goal is to please the principal, so consideration of what the principal wants today is appropriate. Eskridge thus encourages a close analysis of the statutory text, history, and purpose, but he would not end the interpretive inquiry there.

Ultimately, a dynamic statutory interpreter seeks the most just solution. Eskridge decries process theories that seek to produce the

${ }^{39}$ See p. 57 ("[T] determinate answer, in part because different interpreters will bring different perspectives to the reasoning process .....").

${ }^{40}$ P. 176.

11 Pp. 175-76; see also p. 193 (describing the theory as pragmatic because "the interpreter's fidelity to the rule of law is nothing more (and nothing less) than a sympathetic effort to understand a statute in the context of the problem at hand and of ongoing practice").

42 See p. 200 (noting that "no single legal convention governs statutory interpretation, but all are relevant-statutory text, legislative intent or purpose, the best answer" ${ }^{n}$.

13 P. 11.

"1 P. 125; see also pp. 127-28 ("TT]he interpreter must first understand the assumptions underlying the original directive, including its purpose. Then she must figure out how the statute can best meet its goal(s) in a world that is not the world of its framers."). 
right answer-what Congress intended-instead of producing the just answer-what the best policy is. Eskridge's own aspirations

are that statutes respect and protect individual rights, especially those of disadvantaged groups; that broad public interest statutes not be eroded by rent-seeking exceptions; that special interest statutes be narrowly construed; and that statutory schemes be allowed to change over time to adapt their goals to new circumstances and political values. ${ }^{45}$

A dynamic statutory interpreter should "decide close cases against politically salient interests and in favor of interests that have been subordinated in the political process." ${ }^{\text {"6 }}$ Furthermore, "Republican theory would also support interpretive presumptions which correct for dysfunctions in the political process. $\$ 47$

There is much truth in what Eskridge says. Empirically, there is no question that judges (and other statutory interpreters) frequently interpret statutes dynamically. Nor do I dispute the ultimate importance of the justice of the results achieved by any theory of statutory interpretation. ${ }^{48}$ But Eskridge's central claims-that dynamic statutory interpretation is empirically inevitable and normatively desirable-are less convincing. ${ }^{49}$

\section{The Practice of Originalism AND the Practice OF DYNAMIC STATUTORY INTERPRETATION}

Dynamic statutory interpretation is not inevitable. Examples abound in which courts have read statutes according to the plain meaning of the statutory language or consistently with the original legislative intent without asking whether contemporary purposes or

${ }^{45}$ P. 149; see also pp. 157-59 (advocating an approach to statutory interpretation that minimizes the asymmetrical distribution of statutory benefits and costs).

${ }^{46}$ P. 294.

47 Id.

48 "Justice," James Madison once wrote, "is the end of government." THE FEDERALIST No. 51, at 352 (James Madison) (Jacob E. Cooke ed., 1961).

19 For earlier critiques of dynamic statutory interpretation, see Redish \& Chung, supra note 7, at 831-58 (explaining how the transfer of policymaking power to the judiciary under dynamic theories threatens foundational democratic premises and exceeds the practical limitations on the abilities of the judiciary); Rodriguez, supra note 13, at 936-39 (finding a dynamic statutory interpretative approach to be "an incommensurate hybrid of different conceptions of law and interpretation"); David E. Van Zandt, An Alternative Theory of Practical Reason in Judicial Decisions, 65 TUL. L. REV. 775, 787-91 (1991) (criticizing Eskridge's theory of practical reasoning and concluding that "[i]n the end, case $X$ is right because Eskridge and Frickey assert it is right ${ }^{\prime \prime}$ ). 
other dynamic factors support such an interpretation. The obvious meaning of statutory language or an uncontested recognition of legislative intent can also dissuade dissatisfied parties from challenging the meaning of a statute. ${ }^{50}$

Although dynamic statutory interpretation is not inevitable, it is inevitably indeterminate. The sources from which a dynamic statutory interpreter may seek evidence of statutory meaning are limited only by the interpreter's imagination. Moreover, the pragmatic character of dynamic statutory interpretation means that there is no single right answer to an interpretative question. Thus, the indeterminacy of dynamic statutory interpretation far surpasses the indeterminacy of an originalist approach.

Many of the Supreme Court's recent decisions support this conclusion. The Court's rhetoric indicates that it continues to rely on an originalist approach. ${ }^{51}$ When the Court confronts an interpretation that results in a policy it dislikes, it often tells the litigants to ask Congress to amend the statute rather than fix the problem itself. The Court's practice is similar to its rhetoric. Most recent decisions display a decided preference for textualist and other originalist arguments. Eskridge admits as much, yet he insists that dynamic statutory interpretation is inevitable because it is impossible to interpret a statute using only originalist sources. ${ }^{52}$ The Court's recent decisions, however, evidence ways of establishing statutory meaning that, although not eliminating all indeterminacy, are far more determinate and constraining than a dynamic approach.

${ }^{50}$ See Frederick Schauer, Easy Cases, 58 S. CAL. L. REv. 399, $412-20$ (1985) (developing this point in the context of constitutional interpretation).

${ }^{31}$ See, e.g., City of Chicago v. Environmental Defense Fund, 114 S. Ct. 1588, 1591 (1994) (following the "plain meaning" of the statutory language); Central Bank v. First Interstate Bank, 114 S. Ct. 1439, 1446 (1994) (stating that adherence to the statutory language is the starting point in every case involving statutory interpretation); FDIC v. Meyer, 114 S. Ct. 996, 1001 (1994) (observing that in the absence of an express definition, a statutory term shall be construed in accordance with its "ordinary or natural meaning"); Good Samaritan Hosp. v. Shalala, 113 S. Ct. 2151, 2157 (1993) (noting that the "starting point in interpreting a statute is its language"); Estate of Cowart v. Nicklos Drilling Co., 112 S. Ct. 2589, 2594 (1992) (same); Connecticut Nat'l Bank v. Germain, 112 S. Ct. 1146, 1149 (1992) (same); Norfolk \&c W. Ry. v. American Train Dispatchers Ass'n, 499 U.S. 117, 128 (1991) (same); United States v. Ron Pair Enters., 489 U.S. 235, 241 (1989) (noting that the task of resolving a dispute over the meaning of a statute begins "with the language of the statute itself").

${ }^{32}$ See pp. 9-12. 
Consider Brown v. Gardner, ${ }^{53}$ a statutory interpretation case decided by the Supreme Court only a few days before the publication of Dynamic Statutory Interpretation. Gardner involved a provision ( 1151 ) of a statute first enacted in 1924 directing the Department of Veterans Affairs (VA) to compensate for

an injury, or an aggravation of an injury [that occurs] as the result of hospitalization, medical or surgical treatment, or the pursuit of a course of vocational rehabilitation [provided under any of the laws administered by the VA, so long as the injury is] not the result of such veteran's own willful misconduct ....54

Ever since its enactment, the VA interpreted the statute to include a fault component: compensation would be provided for an injury only if it "proximately resulted [from] carelessness, negligence, lack of proper skill, error in judgment, or similar instances of indicated fault" by the VA, or from the occurrence during treatment or rehabilitation of an "accident," defined as an "unforeseen, untoward" event. ${ }^{55}$

Fred Gardner underwent surgery at a VA hospital for a herniated disc, the cause of which was unrelated to his service in the Korean War. Afterward, he complained that the operation produced pain in his left calf, ankle, and foot. He filed a claim for disability benefits under $\S 1151$. Relying on its regulation, the VA denied the claim because Gardner did not show that the VA had acted negligently. Gardner then challenged the VA's seventy-yearold interpretation of the statute requiring a showing of fault. ${ }^{56}$

Gardner was an easy case for the Court. The Court unanimously invalidated the regulation based solely on the plain language of the statute. ${ }^{57}$ Writing for the Court, Justice Souter began by observing "the absence from the statutory language of so much as a word about fault on the part of the VA." ${ }^{58}$ Souter then rejected the VA's argument that the statutory terms "injury" and "as a result of"

53115 S. Ct. 552 (1994).

5438 U.S.C. \$ 1151 (Supp. V 1993).

5538 C.F.R. $\$ 3.358$ (c)(3) (1994). The Solicitor General explained that the VA's interpretation "excludes from compensation only the natural worsening of a veteran's original condition (i.e., a condition not arising out of VA treatment) and the contemplated or reasonably foreseeable consequences of careful medical treatment. ${ }^{n}$ Brief for the Petitioner at 9 n.4, Brown v. Gardner, 115 S. Ct. 552 (1994) (No. 931128), available in Westlaw, Sct-brief database, 1994 WL 233282 [hereinafter Gardner U.S. Pet'rs Br.].

${ }^{56}$ See Gardner, 115 S. Ct. at 554.

${ }^{57}$ See id.

${ }^{58}$ Id. at $554-55$. 
implied a fault requirement, or at least created an ambiguity respecting a fault requirement that should be resolved in favor of the agency. ${ }^{59}$ He did so even though he admitted that the word "injury" could "carry a fault connotation. " Souter explained, "is a creature not of definitional possibilities but of statutory context." 61 Here, the context showed that "injury" could not contain a fault connotation because the "aggravation of an injury" phrase "refers to a condition prior to the treatment in question, and hence cannot carry with it any suggestion of fault attributable to the VA in causing it." ${ }^{\text {62 }}$ Additionally, the word "injury" was used elsewhere in the statute and in analogous statutes without including a fault component. ${ }^{63}$

The statutory context similarly clarified the statutory reference to "as a result of." The natural reading of that language was "simply to impose the requirement of a causal connection between the 'injury' or 'aggravation of an injury' and 'hospitalization, medical or surgical treatment, or the pursuit of a course of vocational treatment." ${ }^{\text {"64 }}$ Two further reasons counseled against reading "as a result of" to incorporate the fault requirement sought by the VA. First, proximate cause-not fault-operates to impose any necessary limit on the nexus between the injury and the treatment (or hospitalization or pursuit of treatment). ${ }^{65}$ The second reason derived from $\$ 1151$ 's compensation for injuries resulting from a veteran's "pursuit of . . . rehabilitation." "If Congress had meant to require a showing of VA fault, it would have been odd to refer to 'the pursuit [by the veteran] of vocational rehabilitation' rather than to 'the provision [by the VA] of vocational rehabilitation."

\footnotetext{
${ }^{59}$ See id. at $555-56$.

${ }^{60} \mathrm{Id}$. at 555 .

${ }^{61} \mathrm{Id}$.

${ }^{62} I d$.
}

is See id. The Court's examples included 38 U.S.C. \$ 1701(1) (1988 \& Supp. V 1993) ("The term 'disability' means a disease, injury, or other physical or mental defect $^{n}$ ) (emphasis added), and 38 U.S.C. $\$ \S 1110,1131$ (1988 \& Supp. V 1993) (both using the term "injury" without any connotation of fault). The Court further noted that the regulatory interpretation of the latter provisions confirmed the absence of a fault requirement. See Gardner, 115 S. Ct. at 555 (citing 38 C.F.R. § 3.310(a)). Additionally, the Court did not respond to the Solicitor General's examples of "injury" used in contexts suggesting a fault requirement. See Gardner U.S. Pet'rs Br., supra note 55, at 13-14 \& n.6.

${ }^{64}$ Gardner, $115 \mathrm{~S}$. Ct. at 555-56.

${ }^{65}$ See id. at 556 (citing W. PAge Keeton et AL., Prosser and KeEton ON THE LAW OF TORTS $\S 42$ (W. Page Keeton ed., 5th ed. 1984)).

${ }^{66} \mathrm{Id}$. at 556. 
The Court made one final textual observation. Section 1151 denies compensation to a veteran for additional disabilities that are the result of the "veteran's own willful misconduct." 67 Section 1151 makes no such limitation on recovery by a veteran based on the VA's misconduct. The Court thus deployed the textual canon that " $[w]$ here Congress includes particular language in one section of a statute but omits it in another section of the same Act, it is generally presumed that Congress acts intentionally and purposely in the disparate inclusion or exclusion."

And that was it. The plain statutory language, read in context, convinced the Court that $\$ 1151$ does not include a fault component. This approach attracted the support of all of the Justices, including newly appointed Justice Breyer, whose prior writings suggested considerable skepticism about a plain-meaning approach. ${ }^{69}$ The discovery of plain statutory meaning was "the end of the matter" for the Court, ${ }^{70}$ although the Court did briefly address the VA's nontextual arguments.

Two of the VA's nontextual arguments assumed that Congress knew how the VA had been interpreting the statute for the last seventy years and had seen no need to legislatively change that interpretation. The VA's congressional-ratification argument asserted that Congress implicitly adopted the VA's interpretation when Congress reenacted the statute in $1934 .^{71} \mathrm{Mr}$. Gardner,

${ }^{67} 38$ U.S.C. § 1151. Mr. Gardner argued that the "willful misconduct" exception "demonstrates that the veteran is protected against even his own negligence, even though contributory negligence was a standard defense in fault-based systems in 1924." Brief for Respondent at 12, Brown v. Gardner, 115 S. Ct. 552 (1994) (No. 931128), available in Westlaw, Sct-brief database, 1994 WL 381835 [hereinafter Gardner Resp. Br.]. The VA took the opposite tack in the United States Court of Veterans Appeals, arguing that the exception implies that compensation is available only when the VA is at fault. See Fred P. Gardner, 1 Vet. App. 584, 587 (1991), affd, 5 F.3d 1456 (Fed. Cir. 1993), and affd, 115 S. Ct. 552 (1994).

${ }^{68}$ Gardner, 115 S. Ct. at 556 (quoting Russello v. United States, 464 U.S. 16, 23 (1983)).

${ }^{69}$ See Breyer, supra note 4, at 847 (defending judicial reliance on legislative history in a broad range of circumstances).

${ }^{70}$ Gardner, 115 S. Ct. at 556 (quoting Good Samaritan Hosp. v. Shalala, 113 S. Ct. 2151, 2157 (1993)).

${ }^{71}$ The VA argued that the administrative interpretations of the 1924 Act before 1934 required a showing of fault before compensation would be authorized. Gardner U.S. Pet'rs Br., supra note 55, at 24-31. The VA also argued that Congress enacted the 1924 act knowing that the common law of medical malpractice did not impose strict liability. $I d$. at $19-20$. Thus, the VA argued that Congress knew or should be presumed to have known of the VA's interpretations when Congress reenacted the predecessor of $\S 1151$ in 1934. Id. at 31-36. 
however, questioned the historical accuracy of the premise that the VA had developed by 1934 a consistent interpretation of $\S 1151$ that included a fault component. ${ }^{72}$ The Court ignored the parties' dispute, simply observing that a congressional-ratification argument fails to save an interpretation that conflicts with plain statutory language. ${ }^{73}$ In any event, the Court found no evidence that Congress was aware of the VA's interpretation when it reenacted the statute in $1934 .^{74}$

The VA's congressional-acquiescence argument focused on what Congress did since the statute was reenacted in 1934. Congress did nothing about the VA's interpretation, although Congress amended the statute several times. Therefore, the VA claimed, Congress was on notice about the agency's interpretation for at least sixty years, and the congressional failure to amend the statute demonstrated that Congress was satisfied with the fault concept developed by the VA. ${ }^{75}$ Again, Mr. Gardner argued that the VA's interpretation provided a moving target, with a variety of interpretations taking shape through various agency pronouncements over the past sixty years. ${ }^{76}$ The Court simply responded with a broad swipe against arguments based upon congressional silence. ${ }^{77}$

This argument gains greater strength because there is a legitimate claim that Congress enacted, rather than reenacted, the statute in 1934. Congress repealed the predecessor of $\S 1151$ in 1933 (along with all other benefits for veterans) because of budgetary pressures resulting from the Great Depression. See Act of Mar. 20, 1933, ch. 3, § 17, 48 Stat. 8, 11; see also Gardiner U.S. Pet'rs Br., supra note 55, at 31-34. Congress then reversed course and reinstated in 1934 what is now $\$ 1151$. See Act of Mar. 28, 1934, ch. 102, $\S 31,48$ Stat. 509, 526. For a year, however, the law was off the books as the result of a deliberate policy decision by Congress. If the original enactment of $\S 1151$ dates back only to 1934 , then there is more support for the argument that Congress knew the accepted meaning of the provision when it enacted the provision into law.

${ }_{72}$ See Gardner Resp. Br., supra note 67, at 23-25.

${ }^{73}$ See Gardner, 115 S. Ct. at 556 (noting that "[w] here the law is plain, subsequent reenactment does not constitute an adoption of a previous administrative construction" (quoting Demarest v. Manspeaker, 498 U.S. 184, 190 (1991))).

${ }^{74}$ See id. at 556-57 (" $[\mathrm{T}] \mathrm{he}$ record of congressional discussion preceding reenactment makes no reference to the VA regulation, and there is no other evidence to suggest that Congress was even aware of the VA's interpretive position.").

75 See Gardner U.S. Pet'rs Br., supra note 55, at 36-41.

${ }^{76}$ See Gardner Resp. Br., supra note 67, at 25-29, 31-33.

77 See Gardner, 115 S. Ct. at 557 (stating that "congressional silence 'lacks persuasive significance" (quoting Central Bank of Denver v. First Interstate Bank of Denver, 114 S. Ct. 1439, 1453 (1994))). The Court added that congressional silence is particularly insignificant "where administrative regulations are inconsistent with the controlling statute." Id. at 557 (citing Patterson v. McLean Credit Union, 491 U.S. 164,175 n.1 (1989)). For Eskridge's discussion of Patterson, see p. 240 (criticizing the 
In the end, the VA sought refuge in general principles of judicial deference to administrative interpretations. ${ }^{78}$ The Court brushed this argument aside, observing that "[a] regulation's age is no antidote to clear inconsistency with a statute. ${ }^{\text {} 79}$ Alternatively, the Court recognized that an agency's consistent interpretation can gain strength merely through the passage of time in "a close case," but the Court found that even this argument would be unavailable to the VA because of the unique history of the agency's relationship with the courts. VA decisions were not subject to judicial review until 1988. ${ }^{80}$ Thus, quoting Judge Archer's opinion for the United States Court of Appeals for the Federal Circuit, the Court remarked that " $[\mathrm{m}]$ any VA regulations have aged nicely simply because Congress took so long to provide for judicial review. ${ }^{81}$

Gardner deflects many of the familiar attacks on the plain meaning rule repeated by Eskridge. For example, the deconstructionist argument that words do not interpret themselves did not trouble the Court. ${ }^{82}$ Even Justice Scalia would acknowledge this much, as Eskridge notes. ${ }^{83}$ In Gardner, however, the context in which the contested terms appeared provided additional evidence of their meaning. That context convinced every member of the Court that there was a determinate answer to the interpretive question posed by Mr. Gardner and the VA.

Patterson Court for exhibiting a skeptical attitude toward precedent even while it pays lip service to stare decisis, unwilling to bootstrap prior interpretations into settled law because of legislative inaction, and disinclined to apply statutes retroactively").

${ }^{78}$ See Reply Brief for the Petitioner at 13-14, Brown v. Gardner, 115 S. Ct. 552 (1994) (No. 93-1128) (citing Chevron U.S.A., Inc. v. Natural Resources Defense Council, Inc., 467 U.S. 837 (1984)), available in Westlaw, Sct-brief database, 1994 WL 440234.

${ }^{79}$ Gardner, 115 S. Ct. at 557.

${ }^{80}$ See id.

${ }^{81}$ Id. (quoting Gardner v. Brown, 5 F.3d 1456, 1463-64 (Fed. Cir. 1993), affd, 115 S. Ct. 552 (1994)). Mr. Gardner advanced another reason why deference to the VA's interpretation was not appropriate: the administrative opinions and other materials on which the VA relied were not publicly available and thus constituted a "secret body of law." Gardner Resp. Br., supra note 67, at 9 n.3, 43.

${ }^{82}$ As Eskridge recounts, "[d]econstruction suggests that there are several different 'reasoned' solutions to an interpretive problem-or no single one." P. 193. "Postmodern theorists believe that traditional legal reasoning is both a malleable language game and a social creation." Id. Feminist theory states that "texts mean nothing until they are applied in concrete contexts." P. 194.

8s See p. 226. But see Frederick Schauer, Formalism, 97 YALE L.J. 509, 524-29 (1988) (rebutting the deconstructionist argument); Shapiro, supra note 3, at 921, 93233 (same). 
Gardner also illustrates the common arguments against interpreting a statute consistently with its plain meaning even when the statutory language is admittedly unambiguous. The Supreme Court has developed exceptions to the plain meaning rule in two situations. The first exception occurs when there is evidence (usually in the legislative history) that Congress actually intended a different result than that suggested by the plain statutory language. A second exception arises when the plain statutory language leads to a result Congress could not have intended.

Eskridge argues that these exceptions swallow the plain meaning rule. Broadly construed, they could, and in some cases would, do just that. ${ }^{84}$ Recently, however, the Court has avoided broad constructions of the exceptions to the plain meaning rule, both in its rhetoric and in its practice. ${ }^{85}$ Plain meaning is now displaced only if the legislative history unequivocally indicates that the enacting Congress meant something else ${ }^{86}$ or if the consequences of that meaning would produce an absurd result. ${ }^{87}$

84 Compare Public Citizen v. United States Dep't of Justice, 491 U.S. 440, 453-54 n.9 (1989) (suggesting that plain meaning will not control when it creates a "disturbingly unlikely," but not "absurd," result) with id. at 470-74 (Kennedy, J., concurring) (noting that only "absurd" results-those that Congress could not have possibly intended-may displace the plain meaning).

${ }^{85}$ For examples of the rhetoric, see Negonsott v. Samuels, 113 S. Ct. 1119, $1122-$ 23 (1993) ("Our task is to give effect to the will of Congress, and where its will has been expressed in reasonably plain terms, that language must ordinarily be regarded as conclusive." (quoting Griffin v. Oceanic Contractors, Inc., 458 U.S. 564, 570 (1982))); Estate of Cowart v. Nicklos Drilling Co., 112 S. Ct. 2: 39, 2594 (1992) (finding that plain meaning is controlling "in all but the most extraordinary circumstance[s]"); Freytag v. Commisioner of Internal Revenue, 111 S. Ct. 2631, 2636 (1991) (observing that plain meaning can be displaced only in "rare and exceptional circumstances"). The Court's recent practice of adhering to plain meaning is described in Schauer, supra note 3, at 231 (noting that cases from the 1989 Term demonstrate that the Court has been "relying, both in fact and in articulated justification, on notions of plain meaning"); see also Frederick Schauer, The Practice of Plain Meaning: A Response to Aleinikoff and Shaw, 45 VAND. L. REV. 715, 716 (1992) (citing others who agree that the Court has given increased weight to plain meaning). But see Eskridge \& Frickey, Foreword, supra note 2, at 78 ("Only Justice Thomas shares Justice Scalia's zeal for text, the whole text, and nothing but the text.").

${ }^{86}$ See, e.g., National Org. for Women, Inc. v. Scheidler, 114 S. Ct. 798, 806 (1994) (suggesting that plain meaning can be overcome by "clearly expressed legislative intent to the contrary" (quoting Reves v. Ernst \& Young, 113 S. Ct. 1163, 1169 (1993))).

87 See, e.g., Central Bank v. First Interstate Bank, 114 S. Ct. 1439, 1454 (1994) (noting that plain language can be overcome if it "would lead to a result 'so bizarre' that Congress could not have intended it" (citing Demarest v. Manspeaker, 498 U.S. 184, 191 (1991))). See generally Veronica M. Dougherty, Absurdity and the Limits of Literalism: Defining the Absurd Result Principle in Statutory Interpretation, 44 AM. U. L. 
Both arguments failed in Gardner. The VA argued that testimony by General Frank Hines, the director of the Veterans' Bureau from 1923 to 1945, demonstrated that the original 1924 Act had a limited purpose: to provide compensation to veterans who were injured at a VA facility "as the result of accident or negligence of treatment or unskillfulness." 88 Unfortunately for the VA, General Hines also testified in favor of a no-fault statute. ${ }^{89}$ The mixed signals sent by General Hines fell far short of an unequivocal indication of congressional intent needed to displace the plain language of $\S 1151$. The legislative history argument thus failed to impress the lower courts, ${ }^{90}$ and the Supreme Court did not even discuss the extensive legislative history unearthed by the parties.

The VA also argued in the lower courts (but not in the Supreme Court) that the plain language of $\S 1151$ 's reference to an "injury resulting in additional disability" produced an absurd result. For example, the VA protested that it made no sense to compensate a veteran for suffering shortness of breath after agreeing to the removal of a diseased lung, or to compensate a veteran for the loss of a limb after consenting to the amputation of a gangrenous limb. ${ }^{91}$ Yet a literal reading of $\$ 1151$ "could encompass any change in the veteran's physical condition as a result of a medical procedure," including the above examples. ${ }^{92} \mathrm{Mr}$. Gardner responded that there was no "additional disability" because the lung or limb would have been destroyed by disease anyway. ${ }^{93}$ The United States

REv. 127 (1994) (analyzing the absurd-result rule); Margaret Gilhooley, Plain Meaning Absurd Results, and the Legislative Purpose: The Interpretation of the Delaney Clause, 40 ADMIN. L. REV. 267 (1988) (arguing that the absurd-result rule supports an interpretation of the Delaney Clause which includes a de minimis exception).

${ }^{88}$ Gardner U.S. Pet'rs Br., supra note 55, at 23-24 (quoting World War Veterans' Legislation: Hearings on H.R. 7320 Before the House Comm. on World War Veterans' Legislation, 68th Cong., 1st Sess. 113 (1924) [hereinafter 1924 Hearings] (testimony of General Hines)).

${ }^{89}$ See 1924 Hearings, supra note 88, at 114.

${ }^{90}$ See Fred P. Gardner, 1 Vet. App. 584, $587-88$ (1991) (stating that legislative history need not be examined if the language of the statute is clear and its meaning plain), aff'd, 5 F.3d 1456 (Fed. Cir. 1993), and aff'd, 115 S. Ct. 552 (1994).

${ }^{91}$ See id. at 587. In the Supreme Court, the Solicitor General used the diseased lung example to show that the statutory language was ambiguous, not that it produced absurd results. Gardner U.S. Pet'rs Br., supra note 55, at 15-16. The Court used the gangrenous limb example in a footnote to explain the problem. See Gardner, $115 \mathrm{~S}$. Ct. at $552,556 \mathrm{n} .3$.

92 Gardner, 1 Vet. App. at 587.

${ }^{93}$ See Transcript of Oral Argument at 26-28, Brown v. Gardner, 115 S. Ct. 552 (1994) (No. 93-1128), available in Westlaw, Sct-oralarg database, 1994 WL 759078 [hereinafter Gardner Oral Argument]. 
Court of Veterans Appeals did not find an absurdity "so clear as to be obvious to most anyone" and pointed to evidence that Congress actually intended a no-fault statute. ${ }^{94}$ The Supreme Court refused to believe that Congress intended to compensate veterans in such situations, ${ }^{95}$ but the Court suggested a possible textual hook for that conclusion instead of dismissing the language of $\S 1151$ for producing an absurd result. ${ }^{96}$

Eskridge sees the absurd results exception as evidence that "following statutory text is not all that is going on in statutory interpretation, and that current interpretive values also have a role to play. ${ }^{n 97}$ Once that concession is made, Eskridge would not limit the exception to "absurd" results. He perceives "no logical reason not to sacrifice plain meaning when it directs an 'unreasonable' result that was probably unintended by Congress." ${ }^{n 8}$ Here Eskridge confuses his empirical argument with his normative argument. The distinction between "unreasonable" results and "absurd" results matters little to a dynamic statutory interpreter who is willing to look beyond the statutory text anyway. But the ability to distinguish an "unreasonable" result from an "absurd" result allows an originalist interpreter to sharply limit the number of cases in which plain meaning is displaced..$^{99}$ Moreover, absurdity can be judged by reference to the enacting Congress rather than to the values of the current Congress. Thus understood, the Court's willingness to depart from a statute's plain meaning when that interpretation

94 See Gardner, 1 Vet. App. at 587 (quoting Public Citizen v. United States Dep't of Justice, 491 U.S. 440, 470-71 (1989) (Kennedy, J., concurring)).

${ }^{95}$ See Gardner, $115 \mathrm{~S}$. Ct. at $556 \mathrm{n.3}$ ("It would be unreasonable, for example, to believe that Congress intended to compensate veterans for the necessary consequences of treatment to which they consented (i.e., compensating a veteran who consents to the amputation of a gangrenous limb for the loss of the limb).").

${ }^{96}$ See Gardner Oral Argument, supra note 93, at 9 (suggesting that "some of the examples [regarding shortness of breath and the loss of a limb] would just not be injuries within the meaning of the statute"); $i d$. at 31-35 (discussing the amount of foreseeability necessary to show that the results of a medical procedure are not an "additional disability"). After the Court's decision in Gardner, the United States Department of Justice advised the VA that "only those injuries that are the certain, or perhaps the very nearly certain, result of proper medical treatment" are excluded from coverage under $\$ 1151$. Justice Department Advises VA on Supreme Court Decision, PR Newswire, Jan. 23, 1995, available in LEXIS, News Library, PRNews File.

97 P. 45.

${ }^{98} \mathrm{Id}$.

${ }^{99}$ See John C. Nagle, Severability, 72 N.C. L. REv. 203, 235-36 (1993) (describing how the plain meaning of a severability clause can be given effect unless it produces an "absurd" result). 
would produce an absurd result does not introduce unlimited indeterminacy into an originalist approach.

In short, Gardner demonstrates that dynamic statutory interpretation is not inevitable. ${ }^{100}$ The Court displayed little interest in the parties' arguments about the justice of an interpretation or the practical effects of an interpretation on the VA, Mr. Gardner, or others. Nor did the Court suggest that the attitudes of the present Congress were worthy of any attention. Instead, the Court employed a number of tools in Gardner-structural arguments and linguistic canons-to establish that the statutory language had a plain meaning. Eskridge fails to sustain his argument that the application of the tools themselves results in just as much indeterminacy as a dynamic approach.

Gardner also illustrates the indeterminacy of dynamic statutory interpretation. Gardner would give a dynamic statutory interpreter fits. Eskridge would probably say that Gardner is a case for dynamic statutory interpretation because the VA had relied on its longstanding interpretation in fixing budget proposals and crafting a comprehensive compensation scheme, and perhaps also because of an implicit congressional delegation to the VA to develop the law regarding veteran compensation programs. ${ }^{101}$

A dynamic statutory interpreter would find multiple arguments in support of the VA's interpretation, including: the age of the regulation, ${ }^{102}$ the purpose served by the fault requirement, ${ }^{103}$ the presumed congressional acquiescence in the VA's longstanding interpretation, ${ }^{104}$ the importance of legislative silence, ${ }^{105}$ the

${ }^{100}$ See Sunstein, supra note 3, at 441 ("Whether normative or positive, the claim that statutory meaning is 'indeterminate' is wildly overstated. Claims about the inevitable indeterminacy of interpretation usually suffer from a failure to take account of the contextual character of linguistic commands.").

${ }^{101}$ See p. 112 (stating that liberal premises support dynamic statutory interpretation when "there has been explicit or implicit statutory delegation of lawmaking authority to agencies and/or courts").

${ }^{102}$ See p. 201 ("Unsettling [a] long-standing practice requires justification beyond statutory plain meaning.").

${ }^{103}$ See p. 220 (recognizing that statutory purpose is relevant in dynamic statutory interpretation).

${ }^{104}$ See p. 249 ("If Congress does not fulfill [its] duty [to respond to judicial and agency interpretations of statutes], the Court is free to presume that the interpretations were correct ...."). Eskridge would accord the greatest presumption of correctness to a building block interpretation "(1) which is authoritative and settled, setting a firm, decisive direction for the statute's development; (2) on which persons subject to the statute have relied in structuring their conduct; and (3) on which public decision-makers have relied in developing further legal rules." Id. Gardner satisfies 
current political consensus for tort reform, ${ }^{106}$ the cost of the alternative interpretation, ${ }^{107}$ and the need for deference to the VA's interpretation. ${ }^{108}$ On the other hand, a dynamic statutory interpreter would have little trouble crafting an interpretation that supported the Court's holding in favor of Mr. Gardner. She would note the absence of a fault requirement in the text, the structural arguments advanced by the Court, the broad public support for veterans' benefits, ${ }^{109}$ and the need to interpret statutes in a manner

the first and third criteria. Additionally, Eskridge would apply the presumption "only when interests hurt by the interpretation have had meaningful access to the legislative process." P. 251. The veterans in Gardner had such access.

${ }^{105}$ See p. 220 (noting that "the silence of legislators can be as significant as their utterances").

${ }^{106}$ The Contract with America, for example, places a strong emphasis on tort reform. See H.R. 956, 104th Cong., 1st Sess. $\$ 102(a)(6)$ (1995) (finding that "the recent explosive growth in product liability actions and punitive damage awards jeopardizes the financial well-being of many industries, and is a particular threat to the viability of the nation's small businesses"); see also 132 CONG. REC. S13,648-01 (daily ed. Sept. 25, 1986) (statement of Sen. Hatch) (arguing that federal tort-reform legislation is needed because state courts have "discarded traditional concepts of tort law that require negligence or recklessness in order to recover in favor of an expanded doctrine of strict liability"). That impulse suggests that the new Republican congressional majority would look favorably on the VA's desire to employ a fault standard.

${ }^{107}$ The VA originally claimed that a contrary decision would cost $\$ 5$ billion over five years, see 138 CoNG. REC. S4040 (daily ed. Mar. 20, 1992), but later reduced that estimate to $\$ 1$ billion, see Brief for Amici Curiae Paralyzed Veterans of America et al. in Support of Respondent at 18-22, Brown v. Gardner, 115 S. Ct. 552 (1994) (No. 931128), available in LEXIS, Genfed Library, Briefs File. After the Supreme Court's decision in Gardner, the VA estimated that the decision would cost $\$ 324.2$ million in 1995. See Hearing on FY96 Budget-Veterans Affairs Before the Senate Veterans Affairs' Comm., 104th Cong., 1st Sess. 6 (1995) (statement of VA Secretary Brown). Whatever the actual cost, the decision has been noticed. See Restore VA Liability Limit, OrEgonIAN (Portland), Jan. 4, 1995, available in Westlaw, Ptldogn database (editorializing that "Congress should quickly correct" the ruling because it "opens up U.S. taxpayers to needless expense").

${ }^{108}$ Eskridge finds the vision in Cheoron, (Chevron U.S.A. v. Natural Resources Defense Council, 467 U.S. 837 (1984)), of agencies as primary statutory interpreters and courts as secondary interpreters to be consistent with the greater accountability of agencies in the political process. See p. 161. None of his qualifications on deference to agency interpretations appear to apply to Gardner. See p. 161 ("Courts should not defer to new agency interpretations when constitutional or other statutory rights are implicated, when the agency is shifting policy dramatically away from congressional preferences and toward presidential ones, or when the agency itself is acting nondeliberatively .....").

${ }^{109}$ See, e.g., Kaiser/Harvard Election Night Survey (K.R.C. Communications Research, Nov. 15, 1994) (summarizing the results of a survey conducted November 8,1994 , in which $93 \%$ of the responding voters opposed a decrease in veterans benefits), available in DIALOG, Poll file. 
favorable to veterans. ${ }^{110}$ Ultimately, then, a dynamic statutory interpreter would have to reach a conclusion based on which interpretation makes the most sense today. The VA and disabled veterans would answer that question differently, and it is unclear which answer the current Congress would provide.

Another example in which a dynamic statutory interpreter would make an easy statutory case hard is Gay Rights Coalition of Georgetown University Law Center v. Georgetown University. ${ }^{111}$ The provision of the D.C. Human Rights Act at issue in Gay Rights Coalition prohibited a school from denying "the use of, or access to, any of its facilities and services to any person otherwise qualified" based on sexual orientation. ${ }^{12}$ A group of gay law students at the Georgetown University Law Center challenged the school's refusal to provide them equal access to university facilities or official university recognition. Georgetown University responded that the Act did not apply to a school whose religious teachings oppose homosexuality. The District of Columbia Court of Appeals held that Georgetown had to provide the students with access to university facilities, but that it did not have to formally recognize

${ }^{110}$ Eskridge proposes a tiebreaker for close cases that would favor the party or group with less access to the legislative process and therefore the party less likely to convince Congress to overturn a contrary decision. See p. 153. Under this theory, Mr. Gardner would win because the federal government has greater access to Congress than veterans do. See id. (ranking certain groups' relative access to Congress to override unfavorable Supreme Court decisions and placing the federal government at the top). Along these lines, Mr. Gardner relied on an interpretive canon that encourages liberal construction of veterans' benefits statutes in favor of veterans. Gardner Resp. Br., supra note 67, at 22. The Court did acknowledge that interpretive doubts should be resolved in favor of a veteran, see Gardner, $115 \mathrm{~S}$. Ct. at 555 (citing King v. St. Vincent's Hosp., 502 U.S. 215, 220 n.9 (1991)), but it did not rely on that canon in reaching its decision. The United States Court of Appeals for the Federal Circuit, however, did rely on that canon in the opinion below. See Gardner v. Brown, 5 F.3d 1456, 1463 (Fed. Cir. 1993) ("The World War Veterans' Act was remedial legislation and as such should be construed broadly to the benefit of the veteran.").

${ }^{111} 536$ A.2d 1 (D.C. 1987). states:

112 D.C. CODE ANN. § 1-2520 (1993). The D.C. Human Rights Act more broadly

It is an unlawful discriminatory practice . . . for an educational institution:

(1) To deny, restrict, or to abridge or condition the use of, or access to, any of its facilities and services to any person otherwise qualified, wholly or partially, for a discriminatory reason, based upon the race, color, religion, national origin, sex, age, marital status, personal appearance, sexual orientation, family responsibilities, political affiliation, source of income or physical handicap of any individual.

Id. 
them. ${ }^{113}$ Congress reacted to the decision by amending the Human Rights Act to exempt religious schools from the sexual orientation provisions, but Georgetown decided to provide the students with the requested facilities and services anyway. ${ }^{114}$

I easily conclude that the plain language of the "facilities and services" provision of the Human Rights Act supported the students' claims. The students sought access to "facilities and services" at the University, and the Human Rights Act guaranteed them precisely that. Moreover, Georgetown apparently denied such facilities and services "based upon" the sexual orientation of the students. ${ }^{115}$ The real issue in the case was not whether the statute's direction to provide facilities and services applied to Georgetown-it plainly didbut rather whether the statute could be applied constitutionally to the university. ${ }^{116}$

A dynamic statutory interpreter would struggle to reach a determinate result in Gay Rights Coalition. Although the plain language of the "facilities and services" provision pushes toward the interpretation advanced by the students, several factors would pull a dynamic statutory interpreter toward the reading of the Human Rights Act favored by Georgetown. A dynamic statutory interpreter would recognize that liberal premises support reading statutes to avoid overenforcement of statutory norms. ${ }^{117}$ Eskridge finds United Steelworkers $v$. Weber ${ }^{118}$-holding that Title VII of the Civil

113 The court determined that the plain language of the Human Rights Act required access to "facilities and services" and that such a result did not violate Georgetown University's free exercise rights. See Gay Rights Coalition, 536 A.2d at 26. 39. By contrast, the Human Rights Act did not require the University to "endorse" a private group of students, and imposing such a requirement would violate the Free Exercise Clause. See id. at 17 (interpreting the Human Rights Act to require Georgetown University to endorse the students "would defeat the plain language of the statute and simultaneously transform the Human Rights Act into a patent invasion of the First Amendment").

114 See p. 182.

115 See Gay Rights Coalition, 536 A.2d at 27-29.

116 The court sought to interpret the statute in accordance with the related (but different) interpretative canons favoring those interpretations that avoid holding statutes unconstitutional or that avoid even having to decide difficult constitutional issues. See id. at 16 . But neither rule affected the court's result. The court concluded that the plain language of the Human Rights Act did not extend to endorsements, thereby rendering gratuitous the court's further conclusion that such an interpretation would violate the Free Exercise Clause. On the other hand, the court required Georgetown to provide access to services and facilities notwithstanding the constitutional issue raised by that interpretation of the Human Rights Act.

117 See p. 136.

${ }^{118} 443$ U.S. 193 (1979). Eskridge describes Weber as "the most controversial 
Rights Act of 1964 does not prohibit private affirmative action plans ${ }^{119}$-defensible on this basis. ${ }^{120}$ The same principle would support Georgetown's reading of the Human Rights Act.

A dynamic statutory interpreter would also try to avoid being "overruled" by the legislature. ${ }^{121}$ Indeed, Eskridge chides the Supreme Court for miscalculating the congressional response that resulted in the legislative reversal of five 1989 civil rights decisions. ${ }^{122}$ But the Gay Rights Coalition court suffered an even speedier legislative reversal. Congress first tried to overturn the decision by denying funds to the District of Columbia. ${ }^{123}$ When the courts invalidated that approach, ${ }^{124}$ Congress proceeded to amend directly the D.C. Human Rights Act to exempt religious institutions from the prohibition on discrimination based on sexual orientation. ${ }^{125}$

Current congressional values would guide a dynamic statutory interpreter deciding Gay Rights Coalition. The congressional reversal of the decision provides some after-the-fact evidence that the court misjudged those values. Beyond that, there was little current societal consensus in 1987 regarding the appropriate treatment of homosexuals in general and the appropriate treatment of homosexuals by the church in particular. Moreover, two developments since 1987 would favor Georgetown in the eyes of a dynamic statutory

statutory decision of the last thirty years." P. 109.

${ }^{119}$ See Weber, 443 U.S. at 208.

${ }^{120}$ See pp. 136, 140; see also p. 173 ("Inspired by the civil rights movement and Brown, I accept Weber. . . but remain skeptical that [it] represents anything more than ambiguous progress.").

${ }_{121}$ See pp. 11-12. The unique status of the District of Columbia makes Gay Rights Coalition the unusual case in which two different legislative bodies enjoy the authority to overrule the decision: the District of Columbia Council and Congress. On the other hand, Congress has the power to overrule any state court decision based on state law in those spheres in which the Constitution authorizes Congress to legislate. Eskridge does not indicate which legislative body should be considered by a dynamic statutory interpreter (indeed, Eskridge rarely discusses state law), but his general concern about legislative overruling suggests that any legislative body with the power to overrule a judicial decision will be relevant to a dynamic statutory interpreter.

122 See p. 262.

${ }^{123}$ See District of Columbia Appropriations Act of 1989, Pub. L. No. 100-462, $\S 145,102$ Stat. 2269, 2269-14.

${ }^{124}$ See Clarke v. United States, 886 F.2d 404, 417 (D.C. Cir. 1989) (holding that the Appropriations Act violated the First Amendment rights of the District of Columbia Council members to express their views as legislators on political issues), vacated as moot, 915 F.2d 699 (D.C. Cir. 1990) (en banc) (holding the action moot after the last extension of the appropriation statute).

${ }^{125}$ See Pub. L. No. 101-168, § 141, 103 Stat. 1267, 1284 (1989). 
interpreter if the case arose today. First, the Religious Freedom Restoration Act, enacted by Congress in 1993, strengthens the rights of religious institutions confronted with the issue faced by Georgetown. ${ }^{126}$ Second, further evidence of current congressional values comes from the rightward movement in the 1994 congressional elections.

Gay Rights Coalition also shows that an interpreter's own values need not determine the answer to a statutory question. ${ }^{127}$ As he explains in his detailed discussion of the case, Eskridge is gay, a professor at the Georgetown University Law Center, and the faculty adviser to the students. ${ }^{128}$ Yet he describes Gay Rights Coalition as "a hard case" with no single right moral answer. ${ }^{129}$ I approach the case from a different perspective, being an evangelical Christian and having lived in Washington at the time with a number of friends (one of whom is now my wife) who worked for Senator Armstrong (the author of the congressional amendment overturning the decision). ${ }^{130}$ But the plain language of the D.C. Human Rights Act makes Gay Rights Coalition an easy statutory interpretation case for me.

To say that dynamic statutory interpretation is not inevitable is not to say that it never occurs. Statutes lend themselves to dynamic interpretation in a number of circumstances. There are,

${ }^{126}$ Religious Freedom Restoration Act of 1993, Pub. L. No. 103-141, 107 Stat. 1488 (1993). See generally Michael S. Paulsen, A RFRA Runs Through It: Religious Freedom and the U.S. Code, 56 MONT. L. REv. 249 (1995) (discussing the ramifications of RFRA on existing laws). The courts have reached conflicting results in determining the application of RFRA to claims of religious-based decisions against unmarried couples. Compare Swanner v. Anchorage Equal Rights Comm'n, 874 P.2d 274 (Alaska 1994) (holding that RFRA does not empower a landlord to exclude unmarried couples because the state has a compelling state interest in preventing discrimination), cert. denied, 115 S. Ct. 460 (1994), with Smith v. Fair Employment and Housing Comm'n, 30 Cal. Rptr. 2d 395, 409-10 (Cal. Ct. App. 1994) (holding that, under RFRA's compelling state interest test, California's interest in prohibiting housing discrimination based on marital status did not outweigh the landlord's right to exclude unmarried, cohabiting tenants in accordance with the landlord's religious beliefs).

${ }^{127}$ Eskridge indicates at several points that an interpreter's own values will inevitably influence statutory interpretation. See pp. 41, 44, 58-60, 237.

${ }^{128}$ See pp. 180, 189.

${ }^{189}$ See pp. 181, 198.

130 The appropriate position of the Church with respect to homosexuality and homosexuals raises issues far beyond the scope of this review. Suffice to say that although I read Scripture differently than Eskridge, see p. 191, I wholeheartedly agree with his observation that "[b]igotry, cruelty, and hypocrisy are inconsistent with the teachings of Jesus Christ-in whose name Christian doctrine is promulgated-as reported in the Gospels." Id. 
of course, numerous instances in which statutory language is not plain even in context. A commonly cited example is the Sherman Act, ${ }^{131}$ which the Supreme Court has treated over the past century as an invitation to construct a body of federal antitrust law. ${ }^{132}$ Eskridge recounts a similar example in his extensive discussion of the dynamic judicial decisions interpreting various federal statutes to authorize labor injunctions during the end of the nineteenth century and the beginning of the twentieth century. ${ }^{133}$ Another instance of dynamic statutory interpretation occurs when statutes expand to coincide with expanded interpretations of the Constitution. ${ }^{134}$ Courts also engage in dynamic statutory interpretation to resolve issues that Congress deliberately avoided when it enacted a statute. A search for legislative intent will not be fruitful if the enacting Congress did not intend anything related to the issue in dispute.

These examples of dynamic statutory interpretation simply show that originalist theories do not produce determinate results in all cases and that courts will turn to dynamic statutory interpretation in some cases. Eskridge, however, makes a much broader claim: dynamic statutory interpretation is inevitable because originalist theories are just as indeterminate as any other theory. ${ }^{135}$ Brown v. Gardner offers just one example where Eskridge is wrong. Originalist theories can produce determinate results in contested cases; dynamic statutory interpretation is not inevitable in all cases. The empirical possibility of both approaches leaves open the normative question of which is the better approach.

\section{DYNAMIC STATUTORY INTERPRETATION AND THE 104TH CONGRESS}

The 1994 congressional election created an inescapable tension between three fundamental tenets of Eskridge's theory. He insists that dynamic statutory interpretation is normatively desirable. $\mathrm{He}$

${ }^{131}$ Ch. 647,26 Stat. $209(1890)$ (codified as amended at 15 U.S.C. $\S \S 1-7$ (1988 \& Supp. V 1993)).

${ }_{132}$ See, e.g., Redish \& Chung, supra note 7, at 868-69.

${ }^{133}$ See pp. 81-109. For a discussion of the Court's treatment of jurisdictional grants as authority to fashion federal common law, see PAUL M. BATOR ET AL., HART AND WECHSLER'S THE FEDERAL COURTS AND THE FEDERAL SYSTEM 883-85 (3d ed. 1988).

${ }^{194}$ See, e.g., Allied-Bruce Terminix Cos. v. Dobson, 115 S. Ct. 834, 839-41 (1995)

(allowing the Federal Arbitration Act to expand with the Commerce Clause).

135 See supra note 13 and accompanying text. 
articulates a normative vision that promotes rights for those who are politically and socially marginalized in the United States. And he maintains that the ultimate measure of any theory of statutory interpretation is the justice of the results it produces. These three tenets could coexist when Eskridge wrote his book: a dynamic statutory interpreter would consult the values of the current Congress when interpreting a statute; the values of Congress for the last forty years have been increasingly receptive to the parties that Eskridge wants to protect; thus, a dynamic statutory interpretation would favor those interests. But now when a dynamic statutory interpreter looks to Congress for interpretive guidance, she finds Newt Gingrich and the Contract with America.

The composition of the 104th Congress thus reveals how dynamic statutory interpretation is normatively questionable in two related areas. A dynamic statutory interpreter wrongly assumes policymaking authority from the political branches. Viewed from the opposite perspective, a dynamic statutory interpreter fails to recognize the need to constrain statutory interpreters. Both failures suggest that dynamic statutory interpretation is unfaithful to the rule of law and to democratic theory as those ideas have been historically understood.

\section{A. Dynamic Statutory Interpretation and Updating Statutes to Reflect Current Congressional Values}

A dynamic statutory interpreter assumes that she enjoys some responsibility for updating statutes to reflect current policies. She faces two challenges in doing so. The first challenge concerns her competence to determine which current policies should guide the interpretation of previously enacted statutes. Although at times Eskridge indicates that a dynamic statutory interpreter may engage in a general inquiry into contemporary social norms, he is most interested in current congressional policy. To ascertain that policy, Eskridge is willing to look at a broad range of formal and informal materials for evidence of Congress's current preferences. ${ }^{136}$

136 See p. 152 (suggesting that "less formal postenactment legislative signals, such as statements in committee reports, can provide useful information to the Court about the nature and intensity of current congressional preferences"); see also James J. Brudney, Congressional Commentary on Judicial Interpretations of Statutes: Idle Chatter or Telling Response?, 93 MICH. L. REV. 1, 7-8 (1994) (defending judicial reliance on particular subsequent legislative signals to avoid imposing opportunity costs on Congress). 
Eskridge's own examples demonstrate the difficulty of this task. He charts how congressional and executive attitudes toward abortion counseling under Title $X$ developed throughout the 1970 s, 1980s, and early 1990s. The Bush Administration promulgated regulations prohibiting abortion counseling in programs receiving federal funds under Title X. In Rust $v$. Sullivan, ${ }^{137}$ the Supreme Court upheld that interpretation as within the range of permissible interpretations of the 1970 legislation. Eskridge criticizes the Bush Administration regulations as contrary to the policy preferences of Congress in the 1980s. ${ }^{138}$ He finishes the story by noting President Clinton's executive orders repealing the Bush Administration regulations prohibiting abortion counseling. ${ }^{139}$

Since then, however, Congress received a new Republican majority that includes three dozen new Representatives of the House and five new Senators who oppose abortion. ${ }^{140}$ This may not be enough to swing the congressional median to a position consistent with the Bush Administration regulations, and it certainly falls short of what would be needed for the inevitable by President Clinton, but it does reveal the precariousness of placing too much reliance on rapidly shifting congressional preferences when interpreting existing legislation. The example also shows the difficulty in ascertaining precisely what a majority in Congress prefers at any given time. The new prolife members of Congress may oppose a Title $\mathrm{X}$ abortioncounseling ban, even though they favor other restrictions on abortion, ${ }^{141}$ but asking a dynamic statutory interpreter to divine such a fine distinction in congressional values asks too much.

Eskridge, no doubt, would respond that the values of Newt Gingrich and the Contract with America are not the values of ... rule.").

137500 U.S. 173 (1991).

${ }^{138}$ See p. 290 (" $[\mathrm{I}] \mathrm{t}$ is clear that Congress in 1991 disagreed with the HHS gag

${ }^{139}$ See p. 381 n.121.

${ }^{140}$ See Spotlight Story the Day After: Pro-Lifers Declare Their Movement Revived, AbORTION REP. (Am. Political Network), Nov. 10, 1994, available in LEXIS, Legis Library, Abtrpt File (quoting a press release issued by the National Abortion Rights Action League); see also The Escalating War on Legal Abortion, N.Y. TIMES, Jan. 28, 1995, at 18 (noting that abortion opponents form a majority in both the House and the Senate).

141 See Richard S. Dunham, Lesson No. 1 for Newt's Rebels: Tactical Retreat, BUS. WEEK, Dec. 26, 1994, at 77, 77 (suggesting that "the GOP is backtracking on promises ... to reinstitute the ban on abortion counseling in federally funded clinics"). 
well, Eskridge never really does say whose values a dynamic interpreter should seek. The closest he comes to identifying such values is in his discussion of median legislature preferences in Rust and Weber. But ascertaining the values of the median legislator in the current Congress with respect to an existing statute is at least as difficult as the originalist tasks Eskridge dismisses as impossible. Nonetheless, Eskridge would surely insist that whoever the median legislator is in the 104th Congress, it is not Newt Gingrich. I accept that. At the same time, by Eskridge's own criteria, Gingrich exercises more influence than any single legislator has possessed for years. He controls the House agenda, he exercises substantial influence over the selection of the House committee chairs, and the political strategy he promotes helped some new members gain their seats-all of which display the kind of power over the legislative agenda that Eskridge finds relevant in gleaning the meaning of a statute. ${ }^{142}$ Moreover, many of Gingrich's ideas are shared by the Republican House members who signed the Contract with America and voted for its provisions with little dissent. That document has provided a legislative blueprint that directs the actions of the 104th Congress. The upshot is that the Contract with America, and Newt Gingrich in particular, can make a powerful claim to embody a significant portion of the 104th Congress.

The second challenge in updating statutes to reflect current policies concerns the authority of a dynamic statutory interpreter to rely on current policies when interpreting an existing statute. Originalist theories deny any such authority. They instead view any statutory changes as the responsibility of the legislature. If a statute needs updating, the legislature should amend it. If the legislature does not do so, and the statute becomes irrelevant because of changed circumstances, so be it. Judicial assumption of this task, by contrast, is countermajoritarian. ${ }^{143}$

Eskridge understands this argument. ${ }^{144}$ Nonetheless, he pro-

${ }^{142}$ See pp. 34-37 (discussing how control of the legislative agenda can break "majority cycling"); see also p. 78 (noting that committee "gatekeeping' power over issues on the legislative agenda" affords "substantial ability to head off overrides, especially if they are supported by the majority party leadership").

${ }^{143}$ Redish and Chung defend this originalist view, specifically concluding that "the framers contemplated and condoned the possibility that statutes would become anachronistic and obsolete; legislative inertia was simply part of the bargain: the cost of attaining political stability by ensuring that society would not be thrown into tumult with every shift in political opinion." Redish \& Chung, supra note 7, at 877.

${ }^{144}$ See p. 298 (recognizing that "[t]he meta-rule indicated by a conservative version of the legal process philosophy is that shifts in national policy should be made by the 
vides a dynamic statutory interpreter with several justifications for departing from the traditional originalist understanding to consciously weigh policy choices. His first claim is historical. Eskridge defends judicial reliance on current values as consistent with, and indeed expected by, the Framers. ${ }^{145}$ He relies on The Federalist No. 78, in which Alexander Hamilton extolls the virtues of an independent judiciary as "an essential safeguard against the effects of occasional ill humors in the society" that result in "unjust and partial laws. ${ }^{146}$ Hamilton deems the judiciary "of vast importance in mitigating the severity, and confining the operation of such laws. ${ }^{147}$ Eskridge reads this as a general invitation for a dynamic statutory interpreter to rely on current congressional values. But Hamilton follows this passage by warning that " $[t] 0$ avoid an arbitrary discretion in the courts, it is indispensable that they should be bound down by strict rules and precedents, which serve to define and point out their duty in every particular case that comes before them." ${ }^{148}$ Hamilton also repeatedly asserts that the judiciary will not substitute its own will for that of the legislature. For example, Hamilton explains:

It can be of no weight to say, that the courts on the pretense of a repugnancy, may substitute their own pleasure to the constitutional intentions of the legislature. ... The courts must declare the sense of the law; and if they should be disposed to exercise WILL instead of JUDGMENT, the consequence would equally be the substitution of their pleasure to that of the legislative body. ${ }^{149}$

political process and not by the courts").

145 See p. 156.

${ }^{146}$ The Federalist No. 78, at 528 (Alexander Hamilton) (Jacob E. Cooke ed., 1961).

${ }^{147} I d$. Hamilton adds that the judiciary

not only serves to moderate the immediate mischiefs of those which may have been passed, but it operates as a check upon the legislative body in passing them; who, perceiving that obstacles to the success of an iniquitous intention are to be expected from the scruples of the courts, are in a manner compelled, by the very motives of the injustice they meditate, to qualify their attempts.

Id.

148 Id. at 529.

${ }^{149} \mathrm{Id}$. at 526; see also THE FEDERALIST No. 81, at 545 (Alexander Hamilton) (Jacob E. Cooke ed., 1961) ("Particular misconstructions and contraventions of the will of the legislature may now and then happen; but they can never be so extensive as to amount to an inconvenience, or in any sensible degree to affect the order of the political system."); id. at 546 ("There never can be danger that the judges, by a series of deliberate usurpations on the authority of the legislature, would hazard the united resentment of the body entrusted with it .... ). Eskridge discounts the first quote 
These are not the words of a dynamic statutory interpreter.

Eskridge also makes a separation of powers argument for interpretive reliance on current congressional values. The Framers, writes Eskridge, wanted "to leave the legislative agenda uncluttered by issues of fine-tuning and application, and relatively free to focus on the major policy issues." 150 Eskridge offers a further defense based on the assumption that the difficulty in enacting statutes implies that they should be expected to remain effective for a lengthy period of time. ${ }^{151}$ He cites no authority for either proposition. The theory of separation of powers underlying both claims is controversial. Martin Redish and Theodore Chung, for example, have argued that dynamic statutory interpretation disserves legislative supremacy; invites judges to exercise a policymaking function unauthorized by the Constitution; and generally overlooks the issue of "who gets to determine what is and is not in the "public interest." 152 Eskridge's assumption that statutes have a long lifespan is further undercut by the many federal statutes that must be periodically reauthorized lest they expire. ${ }^{153}$

from The Federalist No. 78 above as confined to Hamilton's discussion of judicial review, see p. 366 n.32, but the context is not so limited. Similarly, although Eskridge is correct that Hamilton never directly stated that the "will of the Legislature" constrains judicial interpretation of statutes, see $p .118$, the quotes above indicate that Hamilton had that in mind.

${ }^{150}$ P. 132.

151 See p. 48 (asserting that statutes are "aimed at big problems and must last a long time"); pp. 130-31 ("[B]oth liberal theory and the Constitution contemplate that Congress will enact statutes; the assumption in both 1789 and today is that statutes will have an indefinite life-well beyond that of the enacting Congress.").

152 Redish \& Chung, supra note 7, at 852 (emphasis added). For a similar view of the relationship of the constitutional separation of powers to statutory interpretation, see Thomas W. Merrill, The Common Law Powers of Federal Courts, 52 U. CHI. L. REv. $1,19,32-33$ (1985) (discussing the danger of judicial usurpation of federal lawmaking power, which was intended to be vested in the legislative branch). Eskridge discusses the institutional competence of courts and agencies to make statutory policy at pp. 161-73.

${ }^{15 s}$ See, e.g., Endangered Species Act, 16 U.S.C. \$ 1542 (1988) (limiting authorization of appropriations). Several members of the 104th Congress have seized on the necessity of reauthorizing the Endangered Species Act as leverage to seek sweeping changes to the act. See, e.g., Michele Kay, Endangered Species Act Becomes Threatened Itself, AUSTIN AM.-STATESMAN, Jan. 28, 1995, at A13 (suggesting that Congress may decline to appropriate funds for the ESA in order to kill the legislation); William $\mathrm{K}$. Stevens, U.S. Effort to Return Farm Land to Natural State Wins Praise, N.Y. TIMES, Jan. 10,1995 , at $\mathrm{C4}$ ("The issue [of conservation] is expected to get a thorough airing in the new Republican-dominated Congress since . . . the Endangered Species Act [is] up for reauthorization this year."). 
Eskridge next responds to the countermajoritarian difficulty of having unelected judges making new law by observing that our political system is not strictly majoritarian anyway. ${ }^{154}$ This argument confuses the judicial role in interpreting statutes with judicial review for unconstitutionality. ${ }^{155}$ It also undermines the justification for dynamic statutory interpretation. To assume, as Eskridge does, that unenacted majority preferences should be the basis of the interpretation of federal statutes cuts against the constitutional checks on the immediate transformation of majority preferences into law. Eskridge recognizes that the Framers understood the undesirability in immediately translating congressional notions of beneficial public policy into law, ${ }^{156}$ but his argument here neglects it. Eskridge makes the same mistake when he asserts that " $[t] 0$ the extent that the dynamic interpretation is consistent with current legislative desires, the countermajoritarian difficulty is ameliorated. ${ }^{157}$ Interpreting federal statutes consistently with the preferences of Newt Gingrich may now be majoritarian, but the constitutional structure imposes a number of hurdles specifically so that those preferences do not immediately become law. ${ }^{158}$

${ }^{154}$ See p. 156 ("A final response to the countermajoritarian difficulty is to recognize that our polity is not majoritarian.").

${ }^{155}$ Redish and Chung elaborate:

Interpreting a statute already deemed to have passed constitutional muster ... cannot be properly equated with the task of reviewing a statute to determine whether Congress has transgressed the constitutional boundaries that confine its activity. In exercising its power of judicial review, the judiciary is enforcing the counter-majoritarian norms embodied in the Constitution. It makes perfect sense to entrust to the one branch purposely insulated from majoritarian pressures the power to interpret and enforce this document. For issues of social policy not controlled by the Constitution, however, the judiciary lacks authority or legitimacy to act in ways inconsistent with congressional directives. This constraint exists for the very same reason that the judiciary is entrusted with the power of judicial review: its lack of accountability to the electorate.

Redish \& Chung, supra note 7 , at 851 .

${ }^{156}$ See p. 291 (" $[\mathrm{T}]$ he framers did not contemplate that what Congress desired as public policy would immediately become so.").

${ }^{157}$ P. 152.

${ }^{158}$ Abner Greene supports reliance on current congressional values in a much narrower category of cases than Eskridge would allow. See Abner S. Greene, Checks and Balances in an Era of Presidential Lawmaking, 61 U. CHI. L. REV. 123, 193-95 (1994) (proposing to allow current congressional preferences to govern statutory interpretation when Congress passes a concurrent resolution specifically disapproving an executive agency's interpretation of an ambiguous statute). The scenario to which Greene responds occurred in Rust v. Sullivan, 560 U.S. 173 (1991). Congress passed an ambiguous statute; an executive agency interpreted the statute in a manner 
The 104th Congress presents Eskridge with a new problem. There is a growing tension between Eskridge's instruction to rely on current policy values, especially those of Congress, and Eskridge's normative vision. As noted above, Eskridge's aspiration is for statutes to protect individual rights (especially the rights of disadvantaged groups), to eliminate rent-seeking exceptions from broad public-interest statutes, to narrowly construe special-interest statutes, and to enable statutory schemes "to change over time to adapt their goals to new circumstances and political values." 159 These values inform the harsh critique of the Supreme Court's 1989 civil rights cases with which Eskridge concludes his book. ${ }^{160}$

What Eskridge's willingness to allow statutes "to change over time to adapt their goals to new circumstances and political values" means with the 104th Congress is best demonstrated by the Endangered Species Act (ESA). ${ }^{161}$ Few statutes have experienced as great a shift in congressional favor as the ESA. Enacted by Congress by an overwhelming bipartisan majority in $1973,{ }^{162}$ the ESA has steadily lost congressional support since then. The slip probably began with Tennessee Valley Authority $v$. Hill, ${ }^{163}$ in which the Supreme Court interpreted the plain language of the ESA to block the completion of a $\$ 110$ million dollar dam that threatened

contrary to current congressional preferences; the courts upheld the agency's interpretation under Cheuron deference (Chevron U.S.A. v. Natural Resources Defense Council, 467 U.S. 837 (1984)); and the President overrode congressional efforts to amend the statute. See Greene, supra, at 182-83; see also p. 273 (using this as an example of how divided government makes congressional overrides of presidential vetoes "triply difficult"). Although I do not necessarily endorse Greene's proposal, it demonstrates the possibility of limiting consideration of current congressional values to much more narrow circumstances than Eskridge would permit.

159 P. 149.

${ }^{160}$ See pp. 297-306. Eskridge instructs a dynamic statutory interpreter to develop "substantive economic and critical analyses of civil rights and other policy concerns handled by the modern administrative state-and to be guided by those insights rather than by abstract procedural doctrines." P. 274. Although Eskridge does not offer a complete account of his substantive vision on civil rights, Newt Gingrich's views may not be as distant as Eskridge would think. See 139 CoNG. REC. H1479 (daily ed. Mar. 18, 1993) (statement of Rep. Gingrich) (remarking that "there is no problem in America more important than saving the inner city, no problem in America more important than addressing the concerns of the poorest and neediest of Americans").

16116 U.S.C. §§ 1531-1544 (1988 \& Supp. V 1993).

162 The House approved the Act by a vote of 355 to 73. See SENATE COMM. ON ENV'T AND PUB. WORRS, 93D CONG., 1ST SESS., Legislattve History OF THE ENDANGEREd SpeCIES ACT OF 1973, AS AMENDEd IN 1976, 1977, 1978, 1979, AND 1980, at 483-84 (1982). The Senate approved the Act on voice vote, see id. at 474, having passed an earlier version of the bill by a vote of 92 to 0 , see id. at 410 .

163437 U.S. 153 (1978). 
the existence of the tiny snail darter. The ESA has been amended several times to qualify its original unequivocal prohibitions, but much of its sweeping character remains. It has experienced a revival in recent years as environmental groups and the federal government have relied on the Act to block timber sales in the Pacific Northwest that threatened the northern spotted owl. ${ }^{164}$

The 104th Congress appears hostile to the ESA. ${ }^{165}$ Seeing this, a dynamic statutory interpreter would read the ESA narrowly for two reasons: she would want to consider current congressional values, and she would not want to be legislatively overruled. A dynamic statutory interpreter would thus disagree with the Fish and Wildlife Service's broad interpretation of the ESA to prohibit "significant habitat modification." 166 A divided federal court of appeals found the agency's interpretation inconsistent with the ESA, ${ }^{167}$ and the Supreme Court has agreed to resolve the dispute. ${ }^{168}$ The case has generated interest in Congress, where the advocates of amending the ESA have attacked the agency's "errone-

I6t See Albert Gidari, The Endangered Species Act: Impact of Section 9 on Private Landowners, 24 ENVTL. L. 419, 426-40 (1994) (describing the spotted owl controversy); see also Pacific Rivers Council v. Thomas, 30 F.3d 1050, 1056-57 (9th Cir. 1994) (enjoining the U.S. Forest Service from conducting any timber sales, range activities, or road building projects until it engages in required consultation procedures regarding the threatened Snake River chinook salmon).

${ }^{165}$ Legislation has been proposed in the 104 th Congress to impose a moratorium on the listing of endangered and threatened species and the designation of critical habitat for those species. The legislation would also provide compensation to private parties who own property designated as critical habitat. See H.R. 490, 104th Cong., 1st Sess. (1995); S. 191, 104th Cong., 1st Sess. (1995). For additional examples of opposition to the ESA and proposals to amend it, see 141 CONG. REC. E134-01 (daily ed. Jan. 19, 1995) (statement of Rep. Bonilla) (stating that the Act "must be reconstructed with amendments which not only protect the environment, but respect property rights"); 141 CONG. REC. S825 (daily ed. Jan. 12, 1995) (statement of Sen. Packwood) (criticizing "the devastating effects of the sole-purpose Endangered Species Act"); 141 CoNG. REC. S790 (daily ed. Jan. 11, 1995) (statement of Sen. Hutchinson) (proposing legislation "to stop Government overreaching until we have had time to revise the Endangered Species Act"). Another proposed bill would empower the Secretary of the Interior to decide that a particular species is not worth saving. See Timothy Egan, Industries Affected by Endangered Species Act Help a Senator Rewrite Its Provisions, N.Y. TIMES, Apr. 13, 1995, at A20 (describing legislation to be introduced by Sen. Gorton of Washington).

16650 C.F.R. $\$ 17.3$ (defining statutory "harm" to endangered species to "include significant habitat modification or degradation where it actually kills or injures wildlife by significantly impairing essential behavior patterns, including breeding, feeding or sheltering").

${ }^{167}$ See Sweet Home Chapter of Communities for a Great Or. v. Babbitt, 17 F.3d 1463, 1472 (D.C. Cir. 1994).

${ }^{168}$ See 115 S. Ct. 714 (1995). 
ous" interpretation for "depriving people of their private property rights. ${ }^{n 169}$ Such specific congressional signals are valuable to a dynamic statutory interpreter.

But the history of the ESA shows that Congress can be entrusted with updating statutes. Congress has repeatedly amended the ESA to strike a new balance when it disliked the results of an agency or judicial interpretation. Amendments in the aftermath of Tennessee Valley Authority v. Hill established a "God Squad" comprised of designated federal officials authorized to waive the requirements of the Act on a case-by-case basis. ${ }^{170}$ Congress amended the ESA in 1982 to eliminate consideration of economic factors in deciding whether to list a species as endangered or threatened. ${ }^{171}$ The 104th Congress is engaged in a similar process now. ${ }^{172}$ Congress has thus demonstrated the willingness and capacity to balance the competing arguments and reconcile the conflicting norms characteristic of the debate over endangered species. The lesson is that Congress updates a statute when it determines that it is important to do so. Dynamic statutory interpretation based on current but unenacted congressional values is thus unnecessary.

\section{B. Dynamic Statutory Interpretation and Interpretive Constraints}

Originalism is alluring to judges. They continue to use its rhetoric and to rely on it in practice. ${ }^{173}$ Even Eskridge admits that a textualist approach is attractive to a court that is concerned about the rule of law and that wants to avoid giving the impression that it is making law. ${ }^{174}$ In other words, judges who interpret statutes speak and act as if they are constrained.

169140 ConG. REC. H4816 (daily ed. June 22, 1994) (statement of Rep. Tauzin).

${ }^{170}$ See Endangered Species Act Amendments of 1978, Pub. L. No. 95-632, sec. 3, $\S 7,92$ Stat. 3751, 3752.

171 See Pub. L. No. 97-304, 96 Stat. 1411 (1982).

172 See supra note 165 and accompanying text.

173 Even dynamic statutory interpreters succumb to originalist rhetoric. For example, in Taber v. Maine, $45 \mathrm{~F} .3 \mathrm{~d} 598$ (2d Cir. 1995), the court opined that "it is not for us to say whether Feres, even if wise and appropriate when decided, yields appropriate or sensible results today." Id. at 614 (referring to Feres v. United States, 340 U.S. 135 (1950)). These words were written by Judge Calabresi, a prominent dynamic statutory interpreter when he taught at Yale. See Guido CaLABRESI, A COMMON LAW FOR THE AGE OF STATUTES 2 (1982) (endorsing judicial updating of statutes). Eskridge is skeptical of Calabresi's proposal. See pp. 154-55 (noting that "[i]n most cases it is hard to tell what the 'popular will' is, and it is even more doubtful that legal elites are able to discern it reliably").

${ }^{174}$ See p. 272. 
Frederick Schauer has suggested that the Supreme Court's increasing reliance on the plain meaning of statutory text to resolve statutory interpretation cases results from a desire to obtain common ground. ${ }^{175}$ Language works imperfectly, he agrees, but consider the alternatives. A complete understanding of a statute's context may lie beyond a court with limited expertise and resources (and perhaps interest). ${ }^{176}$ Eskridge's call to investigate and weigh current social values would complicate things even further. The more sources examined by a group of interpreters, the less likely they are to agree-especially when it is unclear exactly what they are trying to find. And there is value in agreement. As Justice Ginsburg has explained, "[r]ule of law virtues of consistency, predictability, clarity, and stability may be slighted when a court routinely fails to act as a collegial body," which it does by "too frequent[ly] resort[ing] to separate opinions." ${ }^{177}$ Schauer thus argues that

the reliance on plain meaning may be a hardly novel suboptimizing second-best solution, a way in which people with potentially divergent views and potentially different understandings of what the context would require may still be able to agree about what the language they all share requires. Plain language may provide some minimal mutual understanding that guards something that is shared in the face of widely disparate political views and social experiences. ${ }^{178}$

Brown v. Gardner supports this thesis: the dueling explanations of seventy years of VA and congressional experience with $\S 1151$ could have easily caused the Justices to throw up their hands and look only at the statutory language. In short, a textualist approach constrains the Court; it confines the interpretive inquiry to more manageable proportions and concomitantly increases the probability of obtaining judicial agreement in particular cases.

Eskridge neglects Schauer's argument, a rare omission in his otherwise comprehensive survey of the recent literature of statutory interpretation. Perhaps the omission is because Eskridge is rel-

${ }^{175}$ See Schauer, supra note 3, at 250-56; see also Schauer, supra note 85, at 715 (clarifying and elaborating on his claims about plain meaning).

${ }^{176}$ See Schauer, supra note 3, at 253-54; see also Redish \& Chung, supra note 7, at 856-57.

${ }^{177}$ Ruth B. Ginsburg, Speaking in a Judicial Voice, 67 N.Y.U. L. REV. 1185, 1191 (1992). Ginsburg sees a similar threat from "the immoderate tone of statements diverging from the position of the court's majority." Id.

${ }^{178}$ Schauer, supra note 3, at 254-55. 
atively unconcerned about constraining statutory interpreters. His rejection of originalist theories includes a rejection of traditional sources-statutory text, legislative intent, and statutory purposeeach of which originalist theories rely upon as objective sources outside the interpreter that curb interpretive discretion. The few constraints that Eskridge does note are quite different and less constraining. He sees the "traditions of the surrounding culture and of [the] professional culture" as limiting statutory interpreters. ${ }^{179}$ But the limits imposed by that professional culture derive from precisely those originalist values that Eskridge is willing to sacrifice. Eskridge also views the current Congress and the President as imposing political checks on Supreme Court statutory interpretation, ${ }^{180}$ but the notion of the political process as a constraint suggests that an interpreter need only consider what she can get away with. Eskridge thus invites consideration of congressional values and does little to prevent consideration of a judge's own values. As Schauer has observed, "for the Court to lessen its reliance on plain meaning would serve only to substitute for the community's contingent normative choices the equally contingent and equally normative choices of individual interpreters." 181

Eskridge's willingness to allow those choices to guide statutory interpretation reflects his struggle to determine whether dynamic statutory interpretation is consistent with the rule of law. That question cannot be answered, he writes, because "there is no consensus . . . as to the precise value and implications of democratic theory and the rule of law." 182 "The rule of law sometimes means rules, sometimes means process, and sometimes means values." 183 For Eskridge, the rule of law is merely a sympathetic effort to understand a statute in context, ${ }^{184}$ or "a professional or social practice that respects commonly held conventions, traditions, and priorities." 185

179 P. 65.

180 See p. 69.

${ }^{181}$ Schauer, supra note 3, at 232.

182 P. 108; see also p. 175 (noting that "traditional rule of law or democratic criteria ... are ... elusive in a postmodern world ${ }^{n}$ ).

$18 s$ P. 109.

184 See p. 193 (expressing his belief that "the interpreter's fidelity to the rule of law is nothing more (and nothing less) than a sympathetic effort to understand a statute in the context of the problem at hand and of ongoing practice $\left.{ }^{n}\right)$.

${ }^{185} \mathrm{P}$. 175. Eskridge appears more friendly to traditional rule of law values in other recent writings. See Eskridge \& Ferejohn, The Rule of Law, supra note 2, at 265 (claiming that "a legal system satisfies the requirements of the rule of law if its 
This is a shriveled vision of the rule of law. The historical antithesis of the rule of law is the rule of men. ${ }^{186}$ The core concept is the avoidance of arbitrary government decisionmaking. The Framers demonstrated this concern in formulating the constitutional procedures for the creation of federal law. Article I, Section 7 of the Constitution specifies the formal procedures for the creation of federal law. These procedures delineate the way in which Congress makes policy. Policy changes are accomplished when Congress and the President approve a statute that selfconsciously makes new law. The executive branch agencies and the judiciary then give effect to that new statute in cases to which it applies. Although both the meaning of the statute and Congress's purpose in enacting it may be unclear-even in those situations in which Congress intended for the statute to apply only to particular cases-the interpreter does her best job to remain faithful to the statutory text, purpose, and history. If Congress does not like the result, it can change the law again. ${ }^{187}$

commands are general, knowable, and performable"); Eskridge \& Frickey, Foreword, supra note 2, at 76 (asserting that "[f]or rule of law reasons, the Court owes substantial loyalty to the Congress that enacts the statute," but concluding that "the Court's new-found textualism only exacerbates the normative tension between democracy and the rule of law, and that a more pragmatic approach better serves both democratic and rule-of-law values").

${ }^{186}$ See Morrison v. Olson, 487 U.S. 654, 697 (1988) (Scalia, J., dissenting) ("[T] he judicial shall never exercise the legislative and executive powers, or either of them: to the end it may be a government of laws and not of men." (quoting MASS. CONST. pt. 1, art. 30)). For Justice Scalia's conception of the rule of law, see Antonin Scalia, The Rule of Law as a Law of Rules, 56 U. CHI. L. REv. 1175, 1183, 1185 (1989) (discussing his belief that "the establishment of broadly applicable general principles [rather than narrow, fact-specific holdings] is an essential component of the judicial process" and that "judges cannot create them out of whole cloth, but must find some basis for them in the text that Congress or the Constitution has provided").

${ }^{187}$ The manner in which the rule of law and democratic principles operate to constrain statutory interpreters is discussed in Frank H. Easterbrook, Text, History, and Structure in Statutory Interpretation, 17 HARV. J.L. \& PUB. POL'Y 61, 63-69 (1994) (observing that political society wants to confine judges and that "[ $[1]$ aw does not change in meaning as the political culture changes"); see also Farber, supra note 3, at 298 (describing how the principle of legislative supremacy can constrain statutory interpreters); Bradley C. Karkkainen, "Plain Meaning": Justice Scalia's Jurisprudence of Strict Statutory Construction, 17 HARV. J.L. \& PUB. POL'Y 401, 425 (1994) (contending that "Justice Scalia's strongly held views on separation of powers and the rule of law as a system of constraining rules" drive his theory of statutory interpretation); Mashaw, supra note 11, at 845 (concluding that asking questions regarding constitutional legitimacy "keeps interpreters within the constraints of law"); W. David Slawson, Legislative History and the Need to Bring Statutory Interpretation Under the Rule of Law, 44 STAN. L. REV. 383, 384 (1992) (advocating a "law as statute" theory that would "provide a principled and effective constraint on the use of legislative history"). 
Dynamic statutory interpretation challenges this understanding at nearly every step. Executive agencies may move beyond or even against legislative expectations if they have good policy reasons for doing so. Judges should be concerned about being overruled by the current Congress rather than being completely faithful to the enacting Congress. The only correct interpretation of a statute is one that is consistent with certain preferred normative values which society accepts. In short, Eskridge's view of the rule of law is like his definition of dynamic statutory interpretation: it is defined not by what it is, but by what it is not. ${ }^{188}$

As Eskridge notes, the traditional understanding of the rule of law has become more appealing to those who oppose the conservative direction of the Supreme Court. ${ }^{189}$ The 104th Congress may revive that understanding even further. The meaning of the rule of law and its implications for statutory interpretation merit much greater study, but one simple point shows why dynamic statutory interpretation's view of the rule of law is suddenly less attractive. My sympathy with much (albeit not all) of the Contract with America notwithstanding, it is not the lens through which all federal statutes should now be read.

\section{CONCLUSION}

Anyone who has ever tried to interpret a statute owes a substantial debt to William Eskridge. His writings, culminating in Dynamic Statutory Interpretation, have both disclosed the lack of thought behind many traditional conceptions of statutory interpretation and advanced a forceful argument for a dynamic approach. $\mathrm{He}$ has challenged those who favor a textualist, originalist, or indeed any other theory of statutory interpretation to articulate their position better. And others can certainly learn from his example of applying the insights of disparate legal theories to statutory interpretation. His contribution to the debate is immeasurable.

But Eskridge is far better at exposing the flaws in originalist theories than he is at defending his own vision of dynamic statutory

${ }^{188}$ Daniel Rodriguez argues that Eskridge's view of the rule of law fails to explain "why a court empowered to approach statutes dynamically should be tethered to the language and history of a statute at all." Rodriguez, supra note 13, at 939.

${ }^{189}$ See p. 272 ("The legal community showed renewed interest in the rule of law and constrained judicial decision making in the $1980 \mathrm{~s}$, partly because many of the activist experiments of the Warren and Burger Courts have not turned out well and partly because liberals feared the consequences of an activist Reagan-Bush Court."). 
interpretation. This is so even though he starts with the deck stacked in his favor: it is hard to criticize a theory that presupposes that there is no "right" answer by which to judge an interpretation. Where Eskridge fails is in his overstatement of the dynamism inherent in originalist approaches-particularly in a textualist approach-and in his narrow view of the rule of law.

The increasingly textualist approach followed by the Supreme Court in Brown v. Gardner and numerous other recent cases possesses many of the virtues that a dynamic approach lacks. It produces results that are faithful to the enacting Congress and that are accessible to a casual reader of the statute. It avoids unsolvable disputes about the policy wisdom of the statute. It constrains interpreters-albeit imperfectly, but in a real way nonetheless. It is faithful to-not just sympathetic toward-the rule of law. And it treats the values of Newt Gingrich (or any other legislator) as relevant only if Congress and the President have seen fit to adopt them. Congress is dynamic; the statutes it enacts are not. 